\title{
Proteomic Characterization of Bacteriophage Peptides from the Mastitis Producer Staphylococcus aureus by LC-ESI-MS/MS and the Bacteriophage Phylogenomic Analysis
}

\author{
Ana G. Abril ${ }^{1} \mathbb{D}$, Mónica Carrera ${ }^{2, *} \mathbb{D}$, Karola Böhme $^{3}$, Jorge Barros-Velázquez ${ }^{4} \mathbb{D}$, Benito Cañas ${ }^{5}$, \\ José-Luis R. Rama ${ }^{1}$, Tomás G. Villa ${ }^{1}$ and Pilar Calo-Mata ${ }^{4, *}$ \\ 1 Department of Microbiology and Parasitology, Faculty of Pharmacy, University of Santiago de Compostela, \\ 15898 Santiago de Compostela, Spain; anagonzalezabril@hotmail.com (A.G.A.); \\ joserodrama@gmail.com (J.-L.R.R.); tomas.gonzalez@usc.es (T.G.V.) \\ 2 Department of Food Technology, Spanish National Research Council, Marine Research Institute, \\ 36208 Vigo, Spain \\ 3 Agroalimentary Technological Center of Lugo, 27002 Lugo, Spain; KarolaBoehme@gmx.de \\ 4 Department of Analytical Chemistry, Nutrition and Food Science, School of Veterinary Sciences, \\ University of Santiago de Compostela, 27002 Lugo, Spain; jorge.barros@usc.es \\ 5 Department of Analytical Chemistry, Complutense University of Madrid, 28040 Madrid, Spain; \\ bcanas@quim.ucm.es \\ * Correspondence: mcarrera@iim.csic.es (M.C.); p.calo.mata@usc.es (P.C.-M.)
}

check for updates

Citation: Abril, A.G.; Carrera, M.; Böhme, K.; Barros-Velázquez, J.; Cañas, B.; Rama, J.-L.R.; Villa, T.G.; Calo-Mata, P. Proteomic Characterization of Bacteriophage Peptides from the Mastitis Producer Staphylococcus aureus by LC-ESI-MS/MS and the Bacteriophage Phylogenomic Analysis. Foods 2021, 10, 799. https:/ /doi.org/10.3390/foods10040799

Received: 8 March 2021

Accepted: 6 April 2021

Published: 8 April 2021

Publisher's Note: MDPI stays neutra with regard to jurisdictional claims in published maps and institutional affiliations.

Copyright: (c) 2021 by the authors. Licensee MDPI, Basel, Switzerland. This article is an open access article distributed under the terms and conditions of the Creative Commons Attribution (CC BY) license (https:// creativecommons.org/licenses/by/ $4.0 /)$.

\begin{abstract}
The present work describes LC-ESI-MS/MS MS (liquid chromatography-electrospray ionization-tandem mass spectrometry) analyses of tryptic digestion peptides from phages that infect mastitis-causing Staphylococcus aureus isolated from dairy products. A total of 1933 nonredundant peptides belonging to 1282 proteins were identified and analyzed. Among them, 79 staphylococcal peptides from phages were confirmed. These peptides belong to proteins such as phage repressors, structural phage proteins, uncharacterized phage proteins and complement inhibitors. Moreover, eighteen of the phage origin peptides found were specific to S. aureus strains. These diagnostic peptides could be useful for the identification and characterization of $S$. aureus strains that cause mastitis. Furthermore, a study of bacteriophage phylogeny and the relationship among the identified phage peptides and the bacteria they infect was also performed. The results show the specific peptides that are present in closely related phages and the existing links between bacteriophage phylogeny and the respective Staphylococcus spp. infected.
\end{abstract}

Keywords: pathogen detection; LC-ESI-MS/MS; proteomics; mass spectrometry; phage peptide biomarker

\section{Introduction}

The vast majority of mastitis cases are due to an intramammary infection caused by a microorganism belonging to either the Staphylococcus or Streptococcus genus [1,2]. Staphylococcus aureus is considered one of the major foodborne pathogens that can cause serious food intoxication in humans due to the production of endotoxins; this pathogen remains a major issue in the dairy industry due to its persistence in cows, its pathogenicity, its contagiousness and its ease of colonization of the skin and mucosal epithelia [3-5].

It is well-known that $S$. aureus bacteriophages encode genes for staphylococcal virulence factors, such as Panton-Valentine leucocidin, staphylokinase, enterotoxins, chemotaxisinhibitory proteins or exfoliative toxins [6]. These phages are usually integrated into bacterial chromosomes as prophages, wherein they encode new properties in the host, or vice versa, as transcriptions may hardly be affected by gene disruptions [7]. Phage-encoded recombinases, rather than the host recombinase, RecA, are involved in bacterial genome excisions and integrations $[8,9]$. These integrations may occur at specific bacterial genome sites that are identical to those present in the DNA of the phage, or, as in the case of phage 
$\mathrm{Mu}$ (as long as the given gene is not expressed), some phages can integrate randomly within the bacterial genome. In addition, bacteriophage and staphylococcal species interactions may substantially alter the variability of the bacterial population $[10,11]$.

All known S. aureus phages are composed of an icosahedral capsid filled with doublestranded DNA and a thin, filamentous tail, and they belong to the order Caudovirales (tailed phages) [12,13]. Some Podoviridae family phages, such as the Staphylococcus viruses S13' and S24-1, have been reported, characterized and used in phage therapy against S. aureus infections [14]. There are some well-known Siphoviridae phages of S. aureus, such as the prophage $\varphi$ SaBov, which is integrated into a bovine mastitis-causing $S$. aureus strain [15].

The interaction between bacteria and bacteriophages leads to an exchange of genetic information, which enables bacteria to rapidly adapt to challenging environmental conditions and to be highly dynamic $[11,16]$. As closely related phages normally occupy the same genome location in different bacteria, a specific site in different bacterial strains can be occupied by completely different phages or can be empty.

Conventional culture-based methods have been used for the detection of pathogenic bacteria $[17,18]$ and their phages $[19,20]$; however, at this point, these procedures are timeconsuming and laborious. For this reason, new, rapid molecular microbial diagnostic methods based on genomics and proteomics tools have been developed to achieve faster and more efficient bacterial and bacteriophage identification [1,21-24]. Specifically, phage typing is a classic technique for such purposes [25]. Moreover, biosensors based on phage nucleic acids, receptor-binding proteins (RBPs), antibodies and phage display peptides (PDPs) have been used for pathogen detection [26-30].

Mass spectrometry techniques, such as MALDI-TOF MS (matrix-assisted laser desorption/ionization time-of-flight mass spectrometry) and LC-ESI-MS/MS (liquid chromatographyelectrospray ionization-tandem mass spectrometry), have been used for the analysis and detection of specific diagnostic peptides in pathogenic bacterial strains [31,32]. In addition, LC-ESI-MS/MS methods have been employed for the identification and detection of bacteriophages [19]. In the case of bacteriophage detection and identification by a mass spectrometry analysis, the required production of viruses may be time-consuming. The detection of prophages based on protein biomarkers can be an alternative to genomic detection, and in this sense, proteomic techniques can be cheaper and faster and can ascertain different bacteriophage species by using a single analysis [33]. Based on the specificity of many bacteriophages with their hosts, bacteriophages are considered signal amplifiers; therefore, the detection of peptides from phages is suitable for pathogen identification. For example, Serafim et al. 2017 [33] identified bacteriophage lambda by a LC-ESI-MS/MS analysis. Moreover, the identification of peptides by means of LC-ESIMS/MS from bacteriophage-infected Streptococcus has been performed, which revealed new information on phage phylogenomics and their interactions with the bacteria they infect [19]. However, no study has been published on S. aureus phage detection and identification by LC-ESI-MS/MS or on S. aureus phage characterization without a previous phage purification step. Viral genomic detection and phage display are time-consuming methods. Here, we describe an easy, fast and accurate method for the detection of bacteriophages without the need for the pretreatment of bacterial lysis for bacteriophage replication. This method led to the identification of putative temperate and virulent phages present in the analyzed strains.

A previously published work performed by our laboratory [3] studied the global proteome of several strains of $S$. aureus by shotgun proteomics. Important virulence protein factors and functional pathways were characterized by a protein network analysis. In this work, and for the first time, we aimed to use proteomics to characterize phage contents in different $S$. aureus strains to identify the relevant phage-specific peptides of several S. aureus strains and to identify both phages and bacterial strains by LC-ESI-MS/MS. 


\section{Materials and Methods}

\subsection{Bacteria}

In this study, a total of 20 different $S$. aureus strains obtained from different sources were analyzed (Table S1 in Supplemental Data 2). These strains were previously characterized by MALDI-TOF mass spectrometry [1] after being obtained from the Institute of Science of Food Production of the National Research Council of Italy (Italy) and from the Spanish Type Culture Collection (Spain). The majority of the strains are from food origins, except for strain U17, which is a human clinical strain. Strains ATCC (American Type Culture Collection) 9144 and ATCC 29213 are classified as S. aureus subsp. aureus, while strain ATCC 35845 is categorized as S. aureus subsp. anaerobius. In previous works, the species identification of $S$. aureus and the presence of enterotoxins were evaluated by multiplex polymerase chain reactions (multiplex PCRs) $[3,34,35]$. The strains were reactivated in a brain-heart infusion medium (BHI, Oxoid Ltd., Hampshire, UK) and incubated at $31{ }^{\circ} \mathrm{C}$ for $24 \mathrm{~h}$. Bacterial cultures were then grown on plate count agar (PCA, Oxoid) at $31^{\circ} \mathrm{C}$ for $24 \mathrm{~h}[1,3,36]$. Tubes of broth were inoculated under aerobic conditions.

\subsection{Protein Extraction and Peptide Sample Preparation}

Protein extraction was prepared as described previously [37]. All analyses were performed in triplicate. Protein extracts were subjected to in-solution tryptic digestion [38].

\subsection{Shotgun LC-MS/MS Analysis}

Peptide digests were acidified with formic acid (FA), cleaned on a C18 MicroSpin ${ }^{\mathrm{TM}}$ column (The Nest Group, South-borough, MA, USA) and analyzed by LC-ESI-MS/MS using a Proxeon EASY-nLC II Nanoflow system (Thermo Fisher Scientific, San Jose, CA, USA) coupled to an LTQ-Orbitrap XL mass spectrometer (Thermo Fisher Scientific, San Jose, CA, USA) [3]. Peptide separation $(2 \mu \mathrm{g})$ was performed on a reverse-phase (RP) column (EASY-Spray column, $50 \mathrm{~cm} \times 75 \mu \mathrm{m}$ ID, PepMap C18, 2- $\mu \mathrm{m}$ particles, 100- $\AA$ pore size, Thermo Fisher Scientific, San Jose, CA, USA) with a 10-mm precolumn (Accucore XL C18, Thermo Fisher Scientific, San Jose, CA, USA) using a linear 120-min gradient from $5 \%$ to $35 \%$ solvent B (solvent A: $98 \%$ water, $2 \%$ ACN (Acetonitrile) and $0.1 \%$ FA and solvent B: $98 \% \mathrm{ACN}, 2 \%$ water and $0.1 \% \mathrm{FA}$ ) at a flow rate of $300 \mathrm{~nL} / \mathrm{min}$. For ionization, a spray voltage of $1.95 \mathrm{kV}$ and a capillary temperature of $230^{\circ} \mathrm{C}$ were used. Peptides were analyzed in the positive mode from 400 to 1600 amu $(1 \mu$ scan), which was followed by 10 data-dependent collision-induced dissociation (CID) MS/MS scans (1 $\mu$ scan) using an isolation width of $3 \mathrm{amu}$ and a normalized collision energy of 35\%. Fragmented masses were set in dynamic exclusion for $30 \mathrm{~s}$ after the second fragmentation event, and unassigned charged ions were excluded from the MS/MS analysis.

\subsection{LC-MS/MS Mass Spectrometry Data Processing}

LC-ESI-MS/MS spectra were searched using SEQUEST-HT (Proteome Discoverer 2.4, Thermo Fisher Scientific, San Jose, CA, USA) against the S. aureus UniProt/TrEMBL database $(208,158$ protein sequence entries in July 2020). The following parameters were used: semi-tryptic cleavage with up to two missed cleavage sites and tolerance windows set at $10 \mathrm{ppm}$ for the precursor ions and 0.06 Da for the MS/MS fragment ions. These additional identified semi-tryptic peptides increased the sequence coverage and confidence in protein assignments. The variable modifications that were allowed were as follows: $\left(\mathrm{M}^{*}\right)$ methionine oxidation (+15.99 Da), $\left(\mathrm{C}^{*}\right)$ carbamidomethylation of Cys $(+57.02 \mathrm{Da})$ and acetylation of the N-terminus of the protein $(+42.0106 \mathrm{Da})$. To validate the peptide assignments, the results were subjected to a statistical analysis with the Percolator algorithm [39]. The false discovery rate (FDR) was kept below 1\%. The mass spectrometric data were deposited into the public database PRIDE (Proteomics Identification Database), with the dataset identifier PXD023530. 


\subsection{Selection of Potential Peptide Biomarkers}

For each peptide identified by LC-ESI-MS/MS, we used the BLASTp program to determine the homologies and exclusiveness with protein sequences registered in the NCBI (National Center for Biotechnology Information) database [40]. For the BLASTp search, the Staphylococcus taxon was included and excluded with the aim of finding the peptides that belonged to the Staphylococcus phages, Staphylococcus spp. and only to S. aureus.

\subsection{Phage Genome Comparison and Relatedness}

Genomes of all studied Staphylococcus spp. phages were downloaded from the GenBank database, analyzed and compared using the Web server VICTOR (Virus Classification and Tree Building Online Resource, http://ggdc.dsmz.de/victor.php, accessed on 27 November 2020) for the calculation of the intergenomic distances and the construction of the phylogenomic tree [41].

\section{Results}

\subsection{S. aureus Proteome Repository}

Protein mixtures from each of the 20 different S. aureus strains (Table S1 in Supplemental Data 2) were digested with trypsin and analyzed by LC-ESI-MS/MS.

A total of 1933 nonredundant peptides corresponding to 1282 nonredundant annotated proteins were identified for all S. aureus strains (see the Excel dataset in Supplemental Data 1). Among them, 79 phage peptides were identified. These peptides belong to proteins such as phage repressors, structural phage proteins, uncharacterized phage proteins and complement inhibitors. Figure 1 shows a comparative representation of the different types of phage proteins identified in this study. These phage peptides were selected and analyzed using the BLASTp algorithm. For the BLASTp search, Staphylococcus was included and excluded with the aim of finding peptides belonging to Staphylococcus bacteriophages.

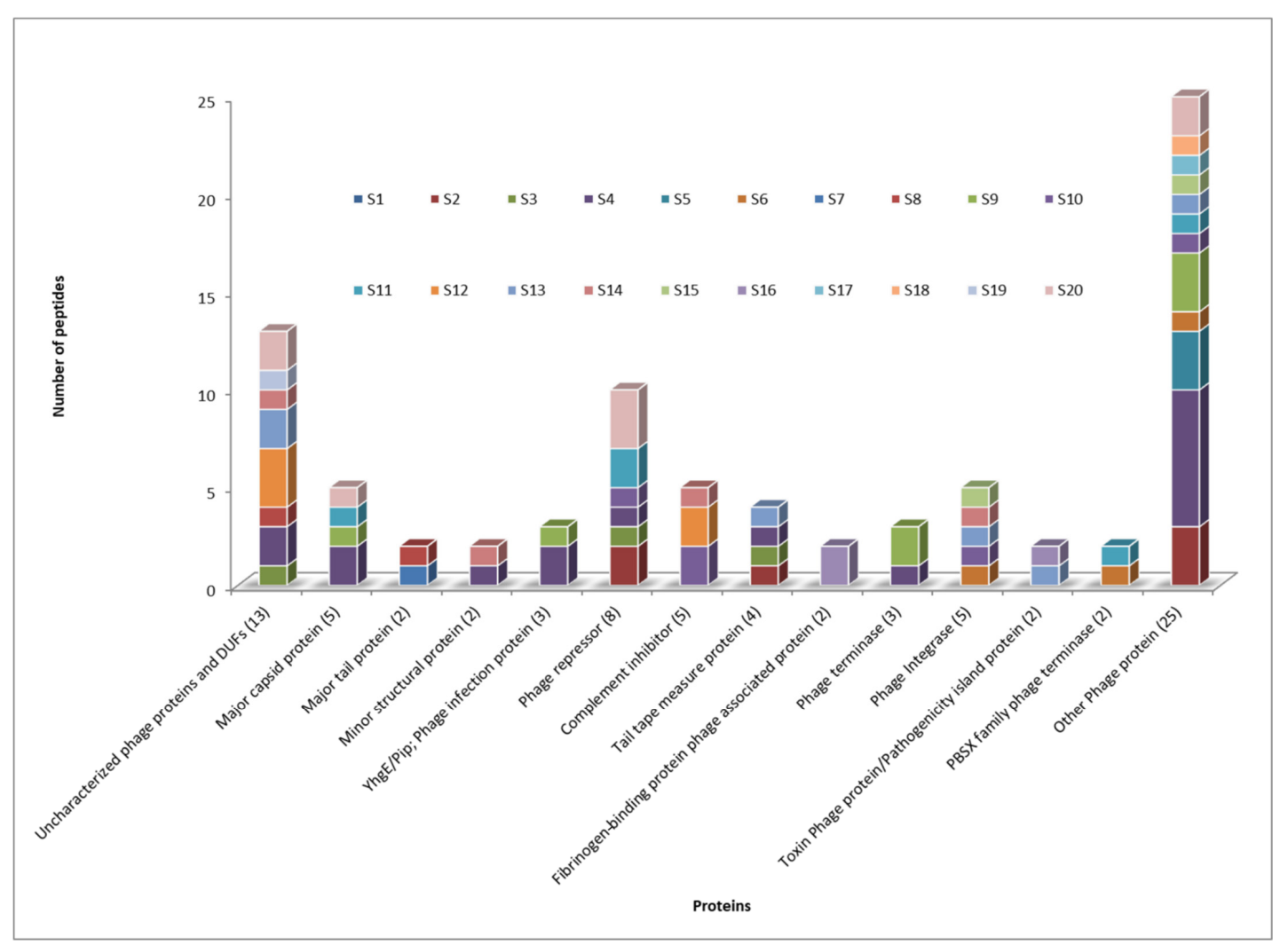

Figure 1. Comparative representation of different types of phage proteins identified in this study for the different strains (represented by different colors). The number of each type of protein is shown in parentheses. 
The obtained staphylococcal phage-specific peptides shared homology with the Staphylococcus phages and Staphylococcus spp. in the NCBI database. Among them, all shared homology with S. aureus; however, eighteen peptides were specific to $S$. aureus (IRLPYYDVK, LYVGVFNPEATK, SIINGKLDSQWTVPNEHK, M*NDSNQGLQANPQYTIHYLSQEITR, PCPALM*NKRNSIATIHR, SQDSNLTPELSTKAPK, ESINANTYINQNLEK, VAVLSTPLVTSFESK, KDGEILFDAIDIYLRNK, MPVYKDGNTGKWYFSI, KTTSEALKEVLSDT, EPKPVDATGADDPLKPDDRM*ITNFHANLVDQKVSY, MSHNALTTGIGIGAGAG, VQHPGKLVNKVM*SGLNINFGGGANATAK, QM*MEGLSGVMDLAAVSGEDLGAVSDIVTDGLTA FGLKAKDSG, KSNVEAFSNAVK, GMVASMQMQVVQVNVLTM*ELAQQNAMLTQQLTELK and DIITVYC*PENGTATDEY). Figure S1 shows the MS/MS spectra for these S. aureusspecific peptide biomarkers. Table 1 summarizes the list of 79 specific staphylococcal bacteriophage peptides, bacterial peptides with putative phage origins and bacteria and phages with $100 \%$ homology with respect to the NCBI protein database.

All staphylococcal phage peptides with 100\% homology were found to belong to the Siphoviridae family: 52 staphylococcal phages belong to the Phietavirus genus, 37 belong to the Biseptimavirus genus, 30 are Triavirus, two are phieta-like viruses and one is a SPbeta-like virus, and the others are nonclassified Siphoviridae viruses (Table S2 in Supplemental Data 2). Siphoviridae genomes are usually organized into functional modules, such as lysogeny, DNA replication, packaging, morphogenesis and lysis modules [6,42].

Table 1. Phage origin peptides identified in Staphylococcus aureus strains. NCBI (National Center for Biotechnology Information).

\begin{tabular}{|c|c|c|c|c|}
\hline Strain & Protein & Peptide & $\begin{array}{l}\text { 3acteria with } 100 \% \text { Homology Based } \\
\text { on the NCBI Protein Database }\end{array}$ & $\begin{array}{c}\text { Phages with } 100 \% \text { Homology Based on the } \\
\text { NCBI Protein Database }\end{array}$ \\
\hline S4 & $\begin{array}{l}\text { Uncharacterized } \\
\text { phage protein }\end{array}$ & IRLPYYDVK & Staphylococcus aureus & Staphylococcus phage StauST398-2 \\
\hline $\mathrm{S} 4$ & $\begin{array}{l}\text { Uncharacterized } \\
\text { phage protein }\end{array}$ & AVAELLKEINR & $\begin{array}{l}\text { Staphylococcus argenteus } \\
\text { Staphylococcus simiae } \\
\text { Staphylococcus aureus }\end{array}$ & $\begin{array}{l}\text { Staphylococcus virus } 71 \\
\text { Staphylococcus virus } 55 \\
\text { Staphylococcus virus } 88\end{array}$ \\
\hline $\mathrm{S} 4$ & Major capsid protein & LLHALPTGNDSGGDKLLPK & $\begin{array}{l}\text { Staphylococcus aureus } \\
\text { Staphylococcus xylosus } \\
\text { Staphylococcus muscae } \\
\text { Staphylococcus haemolyticus } \\
\text { Staphylococcus argenteus } \\
\text { Streptococcus pneumoniae }\end{array}$ & $\begin{array}{c}\text { Staphylococcus phage phiSa2wa_st72 } \\
\text { Staphylococcus phage phiSa2wa_st121mssa } \\
\text { Staphylococcus phage vB_SauS_phi2 } \\
\text { Staphylococcus phage StauST398-2 } \\
\text { Staphylococcus phage LH1 } \\
\text { Staphylococcus phage phiSa2wa_st30 } \\
\text { Staphylococcus virus phi12 } \\
\text { Staphylococcus virus 3a } \\
\text { Staphylococcus virus phiSLT } \\
\text { Staphylococcus phage tp310-2 } \\
\text { Staphylococcus phage vB_SauS_JS02 } \\
\text { Staphylococcus phage R4 } \\
\text { Staphylococcus phage vB_SauS_fPfSau02 } \\
\text { Staphylococcus phage SA137ruMSSAST121PVL }\end{array}$ \\
\hline $\mathrm{S} 4$ & Major capsid protein & RVSYTLDDDDFITDVETAKELKL & $\begin{array}{c}\text { Staphylococcus aureus 12S01399 } \\
\text { Staphylococcus aureus } \\
\text { Staphylococcus aureus A9299 } \\
\text { Staphylococcus aureus A9765 } \\
\text { Staphylococcus argenteus } \\
\text { Staphylococcus aureus A6300 } \\
\text { Staphylococcus sp. } \\
\text { Terrabacteria group } \\
\text { Escherichia coli }\end{array}$ & $\begin{array}{c}\text { Staphylococcus phage LH1 } \\
\text { Staphylococcus phage StauST398-2 } \\
\text { Staphylococcus phage vB_SauS_phi2 } \\
\text { Staphylococcus phage R4 }\end{array}$ \\
\hline S7 & Major tail protein & LYVGVFNPEATK & Staphylococcus aureus & $\begin{array}{l}\text { Staphylococcus phage vB_SauS_phi2 } \\
\text { Staphylococcus virus phi12 } \\
\text { Staphylococcus virus phiSLT } \\
\text { Staphylococcus phage R4 } \\
\text { Staphylococcus phage vB_SauS_JS02 } \\
\text { Staphylococcus phage SH-St } 15644 \\
\text { Staphylococcus virus 3a } \\
\text { Staphylococcus phage P240 }\end{array}$ \\
\hline S8 & $\begin{array}{l}\text { Uncharacterized } \\
\text { phage protein }\end{array}$ & M*NDSNQGLQANPQYTIHYLSQEITR & Staphylococcus aureus & Staphylococcus phage phiN315 \\
\hline
\end{tabular}


Table 1. Cont.

\begin{tabular}{|c|c|c|c|c|}
\hline Strain & Protein & Peptide & $\begin{array}{l}\text { Bacteria with } 100 \% \text { Homology Based } \\
\text { on the NCBI Protein Database }\end{array}$ & $\begin{array}{c}\text { Phages with } 100 \% \text { Homology Based on the } \\
\text { NCBI Protein Database }\end{array}$ \\
\hline S8 & Major tail protein & AYINITGLGFAK & $\begin{array}{l}\text { Staphylococcus aureus } \\
\text { Staphylococcus argenteus } \\
\text { Pararheinheimera mesophila }\end{array}$ & $\begin{array}{c}\text { Staphylococcus phage phiNM3 } \\
\text { Staphylococcus phage P282 } \\
\text { Staphylococcus phage StauST398-4 } \\
\text { Staphylococcus phage phiN315 } \\
\text { Staphylococcus phage phi7247PVL } \\
\text { Staphylococcus phage phiSa2wa_st22 } \\
\text { Staphylococcus virus } 77 \text { Staphylococcus phage } \\
\text { P954 }\end{array}$ \\
\hline S9 & Major capsid protein & IYDRNSDTLDGLPVVNLK & $\begin{array}{l}\text { Staphylococcus aureus } \\
\text { Staphylococcus argenteus }\end{array}$ & $\begin{array}{c}\text { Staphylococcus virus } 85 \\
\text { Staphylococcus phage SP5 } \\
\text { Staphylococcus virus phiETA2 } \\
\text { Staphylococcus phage phiNM2 } \\
\text { Staphylococcus virus SAP26 } \\
\text { Staphylococcus phage SA12 } \\
\text { Staphylococcus virus Baq Sau1 }\end{array}$ \\
\hline $\begin{array}{l}\text { S11 and } \\
\text { S20 }\end{array}$ & $\begin{array}{l}\text { Phage repressor, } \\
\text { Cro/CI family }\end{array}$ & ELAEAIGVSQPTVSNWIQQTK & $\begin{array}{l}\text { Staphylococcus aureus } \\
\text { Staphylococcus argenteus } \\
\text { Staphylococcus sciuri }\end{array}$ & $\begin{array}{c}\text { Staphylococcus virus IPLA35 } \\
\text { Staphylococcus phage SMSAP5 } \\
\text { Staphylococcus phage vB_SauS_phi2 }\end{array}$ \\
\hline $\begin{array}{l}\text { S11 and } \\
\text { S20 }\end{array}$ & $\begin{array}{l}\text { Phage repressor, } \\
\text { Cro/CI family }\end{array}$ & IQQLADYFNVPK & $\begin{array}{c}\text { Staphylococcus aureus } \\
\text { Staphylococcus sciuri } \\
\text { Staphylococcus pseudintermedius } \\
\text { Staphylococcus devriesei } \\
\text { Staphylococcus warneri } \\
\text { Staphylococcus capitis } \\
\text { Staphylococcus argenteus }\end{array}$ & $\begin{array}{c}\text { Staphylococcus phage SMSAP5 } \\
\text { Staphylococcus phage vB_SauS_phi2 } \\
\text { Staphylococcus virus IPLA35 }\end{array}$ \\
\hline $\begin{array}{l}\text { S12 } \\
\text { S10 and } \\
\text { S14 }\end{array}$ & Complement inhibitor & IYNEIDEALKSK & $\begin{array}{l}\text { Staphylococcus aureus, Enterobacter sp. } \\
\text { IF2SW-B1 Klebsiella pneumoniae }\end{array}$ & $\begin{array}{c}\text { Staphylococcus phage } 13 \\
\text { Staphylococcus phage phiNM3 } \\
\text { Staphylococcus phage StauST398-1 }\end{array}$ \\
\hline $\mathrm{S} 20$ & Major capsid protein & VSYTLDDDDFITDVETAK & $\begin{array}{c}\text { Staphylococcus aureus } \\
\text { Staphylococcus haemolyticus } \\
\text { Staphylococcus saprophyticus } \\
\text { Staphylococcus warneri } \\
\text { Staphylococcus argenteus } \\
\text { Streptococcus pneumoniae } \\
\text { Staphylococcus sciuri }\end{array}$ & $\begin{array}{c}\text { Staphylococcus phage phiSa2wa_st72 } \\
\text { Staphylococcus phage tp310-2 } \\
\text { Staphylococcus phage phiSa2wa_st121mssa } \\
\text { Staphylococcus phage vB_SauS_phi2 } \\
\text { Staphylococcus phage StauST398-2 } \\
\text { Staphylococcus virus 3a } \\
\text { Staphylococcus phage LH1 } \\
\text { Staphylococcus phage phiSa2wa_st30 } \\
\text { Staphylococcus virus phi12 } \\
\text { Staphylococcus virus phiSLT } \\
\text { Staphylococcus phage vB_SauS_JS02 } \\
\text { Staphylococcus phage R4 } \\
\text { Staphylococcus phage vB_SauS_fPfSau02 } \\
\text { Staphylococcus phage SA137ruMSSAST121PVL }\end{array}$ \\
\hline S20 & $\begin{array}{l}\text { Phage protein } \\
\text { (DUF2479 domain) }\end{array}$ & SIINGKLDSQWTVPNEHK & Staphylococcus aureus & $\begin{array}{l}\text { Staphylococcus phage DW2 } \\
\text { Staphylococcus virus IPLA88 }\end{array}$ \\
\hline S18 & $\begin{array}{l}\mathrm{N} \text {-acetylmuramoyl-L- } \\
\text { alanine } \\
\text { amidase }\end{array}$ & KEAGNYTVANVK & $\begin{array}{c}\text { Bacilli, Staphylococcus argenteus } \\
\text { Staphylococcus aureus Staphylococcus sp. } \\
\text { HMSC } 34 \mathrm{H} 10\end{array}$ & $\begin{array}{c}\text { Staphylococcus phage tp310-1 Staphylococcus } \\
\text { phage tp310-2 Staphylococcus phage } \\
\text { phi2958PVL Staphylococcus phage PVL } \\
\text { Staphylococcus phage SA137ruMSSAST121PVL } \\
\text { Staphylococcus virus IPLA35 }\end{array}$ \\
\hline $\mathrm{S} 4$ & Phage protein NrdI & $\begin{array}{l}\text { VETFLENETNQNNLIAVM* } \\
\text { SSGNRNWGTNFAIAGDTISK }\end{array}$ & $\begin{array}{c}\text { Staphylococcus haemolyticus } \\
\text { Staphylococcus hominis } \\
\text { Staphyloccus aureus Staphylococcus } \\
\text { aureus subsp. aureus Z172 }\end{array}$ & \\
\hline $\mathrm{S} 12$ & Complement inhibitor & IYNEIDEALK & $\begin{array}{l}\text { Staphylococcus. Aureus } \\
\text { Klebsiella pneumoniae } \\
\text { Enterobacter sp. IF2SW-B1 }\end{array}$ & $\begin{array}{l}\text { Staphylococcus phage StauST398-1 } \\
\text { Staphylococcus virus } 13\end{array}$ \\
\hline $\mathrm{S} 10$ & Complement inhibitor & IYNEIDEALKSKY & $\begin{array}{l}\text { Staphylococcus. aureus } \\
\text { Klebsiella pneumoniae } \\
\text { Enterobacter sp. IF2SW-B2 }\end{array}$ & $\begin{array}{l}\text { Staphylococcus phage StauST398-1 } \\
\text { Staphylococcus virus } 13\end{array}$ \\
\hline $\mathrm{S} 10$ & $\begin{array}{l}\text { DDE-type inte- } \\
\text { grase/transposase/ } \\
\text { recombinase }\end{array}$ & PC*PALM*NKRNSIATIHR & Staphylococcus aureus & \\
\hline S9 & $\begin{array}{l}\text { DNA primase } \\
\text { phage-associated }\end{array}$ & $\begin{array}{c}\text { LLHHFYNPENTTALSF } \\
\text { NDLNDKFKPANLQGKLVNIAD }\end{array}$ & $\begin{array}{c}\text { Staphylococcus aureus, Staphylococcus } \\
\text { haemolyticus Staphylococcus capiti, } \\
\text { Staphylococcus epidermidis } \\
\text { Staphylococcus warneri Staphylococcus sp. } \\
\text { HMSC077D08 Corynebacterium } \\
\text { propinquum, Staphylococcus sp. U } \\
\text { Staphylococcus lugdunensis } \\
\text { Staphylococcus sp. HMSC077B09 }\end{array}$ & Uncultured Caudovirales Phage \\
\hline
\end{tabular}


Table 1. Cont.

\begin{tabular}{|c|c|c|c|c|}
\hline Strain & Protein & Peptide & $\begin{array}{l}\text { Bacteria with } 100 \% \text { Homology Based } \\
\text { on the NCBI Protein Database }\end{array}$ & $\begin{array}{c}\text { Phages with } 100 \% \text { Homology Based on the } \\
\text { NCBI Protein Database }\end{array}$ \\
\hline S2 & $\begin{array}{l}\text { Phage repressor, } \\
\text { Cro/CI family }\end{array}$ & AAHLEGELTDDEWQR & $\begin{array}{c}\text { Staphylococcus haemolyticus } \\
\text { Staphylococcus warneri Staphylococcus } \\
\text { agnetis, Staphylococcus chromogenes } \\
\text { Staphylococcus haemolyticus } \\
\text { Staphylococcus sp. 58-22 Staphylococcus } \\
\text { capitis Staphylococcus pasteuri } \\
\text { Bacillales Staphylococcus chromogenes } \\
\text { Staphylococcus agnetis } \\
\text { Escherichia coli, Staphylococcus aureus } \\
\text { 08-02906 } \\
\text { Staphylococcus aureus VET0383R, } \\
\text { Staphylococcus aureus VET0098R } \\
\text { Staphylococcus aureus M1487 } \\
\text { Staphylococcus aureus, Staphylococcus } \\
\text { aureus A6300 Staphylococcus aureus } \\
\text { subsp. aureus str. Newman } \\
\text { Staphylococcus aureus subsp. aureus } \\
\text { WBG10049, Staphylococcus aureus } \\
\text { A9635, Staphylococcus aureus subsp. } \\
\text { aureus MN8 }\end{array}$ & $\begin{array}{c}\text { Staphylococcus virus } 71 \text { Staphylococcus phage } \\
\text { phiSa2wa_st1 Staphylococcus phage } \\
\text { phiSa2wa_st5 Staphylococcus phage Henu2 } \\
\text { Staphylococcus phage ROSA Staphylococcus } \\
\text { phage phi7401PVL }\end{array}$ \\
\hline S2 & $\begin{array}{l}\text { Phage repressor, } \\
\text { Cro/CI family }\end{array}$ & VLDYADYIR & $\begin{array}{c}\text { Staphylococcus aureus Staphylococcus } \\
\text { epidermidis } \\
\text { Staphylococcus warneri } \\
\text { Staphylococcus agnetis Staphylococcus } \\
\text { warneri Staphylococcus chromogenes, } \\
\text { staphylococcus spp. } \\
\text { Staphylococcus schleiferi Staphylococcus } \\
\text { simulans Staphylococcus haemolyticus, } \\
\text { Staphylococcus pettenkoferi } \\
\text { Staphylococcus lugdunensis } \\
\text { Escherichia coli }\end{array}$ & $\begin{array}{c}\text { Staphylococcus virus } 71 \text { Staphylococcus phage } \\
\text { phiSa2wa_st1 Staphylococcus phage } \\
\text { phiSa2wa_st5 } \\
\text { Staphylococcus phage Henu2 } \\
\text { Staphylococcus phage ROSA Staphylococcus } \\
\text { phage phi7401PVL }\end{array}$ \\
\hline S9 & DNA-binding protein & SLDNM*SLK & $\begin{array}{c}\text { Striga asiática } \\
\text { Staphylococcus aureus subsp. aureus } \\
\text { 112808A Staphylococcus aureus A8819 } \\
\text { Staphylococcus argenteus } \\
\text { Staphylococcus spp. } \\
\text { Pseudomonas aeruginosa } \\
\text { Flectobacillus sp. BAB-3569 } \\
\text { Eoetvoesia caeni } \\
\text { Arabidopsis thaliana, Coxiellaceae } \\
\text { bacterium, Clostridia bacterium }\end{array}$ & Staphylococcus phage vB_SauS_phi2 \\
\hline S19 & $\begin{array}{c}\text { DUF2479, Phage tail } \\
\text { fiber, BppU family } \\
\text { phage baseplate upper } \\
\text { protein }\end{array}$ & HAGYVRC*KLF & $\begin{array}{c}\text { Staphylococcus aureus, Staphylococcus sp. } \\
\text { HMSC055H07 Staphylococcus argenteus, } \\
\text { Staphylococcus sp. KY49P Staphylococcus } \\
\text { sp. HMSC035F11 Pseudomonas } \\
\text { aeruginosa Escherichia coli }\end{array}$ & $\begin{array}{c}\text { Staphylococcus phage SA97 } \\
\text { Staphylococcus virus 55 } \\
\text { uncultured Caudovirales phage Staphylococcus } \\
\text { virus } 85 \text { Staphylococcus virus } 80 \\
\text { Staphylococcus virus phiETA3 } \\
\text { Staphylococcus virus phiETA2 Staphylococcus } \\
\text { phage 55-2 Staphylococcus phage B166 } \\
\text { Staphylococcus phage B236 Staphylococcus virus } \\
\text { SAP26 Staphylococcus virus } 88 \text { Staphylococcus } \\
\text { virus phiETA Staphylococcus virus } 11 \\
\text { Staphylococcus phage SP5 Staphylococcus virus } \\
\text { 69 Staphylococcus phage ROSA Staphylococcus } \\
\text { phage TEM123 Staphylococcus virus } 92 \\
\text { Staphylococcus phage StauST398-1 } \\
\text { Staphylococcus virus phiNM2 Staphylococcus } \\
\text { virus phiNM1 Staphylococcus virus } 29 \\
\text { Staphylococcus phage vB_SauS-SAP27 } \\
\text { Staphylococcus virus } 80 \text { alpha Staphylococcus } \\
\text { phage HSA84 } \\
\text { Staphylococcus virus phiMR11 } \\
\text { Staphylococcus phage SAP33 } \\
\text { Staphylococcus phage 3MRA }\end{array}$ \\
\hline $\mathrm{S} 12$ & $\begin{array}{l}\text { Phage protein } \\
\text { (DUF4393 domain) }\end{array}$ & NSPIDLNSTEISLNNLER & $\begin{array}{l}\text { Staphylococcus aureus } \\
\text { Staphylococcus spp. } \\
\text { Staphylococcus argenteus }\end{array}$ & Staphylococcus phage StauST398-1 \\
\hline $\mathrm{S} 12$ & $\begin{array}{l}\text { Phage protein } \\
\text { (DUF669 domain) }\end{array}$ & MNFNLNLQGAQELGN & $\begin{array}{c}\text { Staphylococcus capitis } \\
\text { Staphylococcus epidermidis } \\
\text { Staphylococcus caprae Staphylococcus } \\
\text { devriesei Staphylococcus warneri }\end{array}$ & Staphylococcus virus phiMR11 \\
\hline $\mathrm{S} 10$ & $\begin{array}{c}\text { GNAT family } \\
\text { N-acetyltransferase }\end{array}$ & IINYARQNNYESLLTSIVSNNIGAK & $\begin{array}{c}\text { Staphylococcus aureus Staphylococcus } \\
\text { aureus subsp. anaerobius } \\
\text { Staphylococcus aureus subsp. } \\
\text { aureus Mu50 } \\
\text { Staphylococcus hominis } \\
\text { Escherichia coli }\end{array}$ & \\
\hline
\end{tabular}


Table 1. Cont.

\begin{tabular}{|c|c|c|c|c|}
\hline Strain & Protein & Peptide & $\begin{array}{l}\text { Bacteria with } 100 \% \text { Homology Based } \\
\text { on the NCBI Protein Database }\end{array}$ & $\begin{array}{c}\text { Phages with } 100 \% \text { Homology Based on the } \\
\text { NCBI Protein Database }\end{array}$ \\
\hline S5 & $\begin{array}{l}\text { Holin, phage phi LC3 } \\
\text { family }\end{array}$ & SQDSNLTPELSTKAPK & Staphylococcus aureus & $\begin{array}{l}\text { Staphylococcus phage HSA84 } \\
\text { Staphylococcus phage SP5 }\end{array}$ \\
\hline S6 & $\begin{array}{l}\text { ImmA/IrrE family } \\
\text { metallo-endopeptidase }\end{array}$ & $\begin{array}{l}\text { EKAKIFGDFDMNDSGVY } \\
\text { DEENSTIIYNPLDSITR }\end{array}$ & $\begin{array}{c}\text { Staphylococcus aureus subsp. aureus } \mathrm{H} 19 \\
\text { Staphylococcus aureus } \\
\text { Staphylococcus aureus subsp. aureus } \\
\text { Staphylococcus aureus subsp. aureus } \\
21204\end{array}$ & \\
\hline
\end{tabular}

\begin{tabular}{|c|c|c|c|c|}
\hline S16 & $\begin{array}{l}\text { Involved in the } \\
\text { expression of } \\
\text { fibrinogen-binding } \\
\text { protein phage-associated }\end{array}$ & ESINANTYINQNLEK & Staphylococcus aureus & \\
\hline S16 & $\begin{array}{l}\text { Involved in the } \\
\text { expression of } \\
\text { fibrinogen-binding } \\
\text { protein phage-associated }\end{array}$ & VAVLSTPLVTSFESK & Staphylococcus aureus & \\
\hline S17 & $\begin{array}{l}\text { N-6 DNA methylase; } \\
\text { N6_Mtase } \\
\text { domain-containing } \\
\text { protein }\end{array}$ & KDGEILFDAIDIYLRNK & Staphylococcus aureus & Staphylococcus phage phi- 42 \\
\hline S4 & $\begin{array}{l}\text { Phage DNA-binding } \\
\text { protein }\end{array}$ & GDM*FVVITIM*MQQIK & $\begin{array}{l}\text { Staphylococcus aureus } \\
\text { Staphylococcus warneri }\end{array}$ & \\
\hline S9 & Phage terminase & KLYIIEEYVKQGM & $\begin{array}{l}\text { Staphylococcus aureus Staphylococcus } \\
\text { argenteus Staphylococcus sp. } \\
\text { HMSC58E11 Allobacillus sp. SKP4-8 }\end{array}$ & $\begin{array}{c}\text { Staphylococcus virus Baq_Sau1 Staphylococcus } \\
\text { virus phiETA2 Staphylococcus virus } 69 \\
\text { Staphylococcus virus } 11 \\
\text { Staphylococcus virus } 80 \text { alpha }\end{array}$ \\
\hline S14 & Integrase & M*PVYKDGNTGKWYFSI & Staphylococcus aureus & $\begin{array}{l}\text { Staphylococcus phage B166 Staphylococcus virus } \\
\text { phiMR25 Staphylococcus virus } 88\end{array}$ \\
\hline S4 & Phage repressor & ISKVQQLADYFNVPK & $\begin{array}{c}\text { Staphylococcus aureus, Staphylococcus } \\
\text { chromogenes } \\
\text { Staphylococcus hyicus }\end{array}$ & Staphylococcus virus 80 \\
\hline $\mathrm{S} 13$ & $\begin{array}{l}\text { Toxin Phage protein; } \\
\text { Pathogenicity island } \\
\text { protein }\end{array}$ & NLDGVWLGDLILIKRGLSDR & $\begin{array}{c}\text { Staphylococcus aureus, Staphylococcus sp. } \\
\text { HMSC58E11, Staphylococcus argenteus, } \\
\text { Escherichia coli }\end{array}$ & $\begin{array}{l}\text { Staphylococcus phage phiSa2wa_st80 } \\
\text { Staphylococcus phage 3MRA } \\
\text { Staphylococcus phage phiSa2wa_st5 }\end{array}$ \\
\hline S16 & $\begin{array}{l}\text { Toxin Phage protein; } \\
\text { Pathogenicity island } \\
\text { protein }\end{array}$ & SDREKAGILFEELAHNK & $\begin{array}{c}\text { Staphylococcus aureus } \\
\text { Escherichia coli } \\
\text { Staphylococcus argenteus Staphylococcus } \\
\text { sp. HMSC58E11 }\end{array}$ & $\begin{array}{l}\text { Staphylococcus phage 3MRA Staphylococcus } \\
\text { phage phiSa2wa_st5 Staphylococcus phage } \\
\text { phiSa2wa_st80 Staphylococcus phage phiJB } \\
\text { Staphylococcus phage phi7401PVL }\end{array}$ \\
\hline S6 & $\begin{array}{l}\text { PBSX family phage } \\
\text { terminase }\end{array}$ & $\begin{array}{l}\text { QADNTYVHHSTYLNNP } \\
\text { FISKQFIQEAESAKQR }\end{array}$ & Staphylococccus spp. & \\
\hline S11 & $\begin{array}{l}\text { PBSX family phage } \\
\text { terminase }\end{array}$ & QGVSHLFKVTKSPM*R & $\begin{array}{c}\text { Staphylococcus aureus Staphylococcus } \\
\text { lentus Staphylococcus sciuri }\end{array}$ & \\
\hline S20 & $\begin{array}{l}\text { Phage-related cell wall } \\
\text { hydrolase; Peptidase } \\
\text { C51; CHAP domain- }\end{array}$ & EVPNEPDYIVIDVC*EDYSASK & $\begin{array}{l}\text { Staphylococcus argenteus } \\
\text { Staphylococcus sp. HMSC36F05 }\end{array}$ & $\begin{array}{l}\text { Staphylococcus virus IPLA88 Staphylococcus } \\
\text { virus phiNM2 Staphylococcus phage SAP40 } \\
\text { Staphylococcus phage phi } 53 \text { Staphylococcus } \\
\text { virus phiNM4 Staphylococcus phage SA12 } \\
\text { Staphylococcus virus } 69 \text { Staphylococcus phage } \\
\text { SA97 Staphylococcus phage TEM123 } \\
\text { Staphylococcus virus } 11 \text { Staphylococcus virus } \\
\text { phiMR25 Staphylococcus virus } 53 \\
\text { Staphylococcus phage SAP33 }\end{array}$ \\
\hline S5 & Phage antirepressor Ant & QDWLAM*EVLPAIR & $\begin{array}{l}\text { Staphylococcus aureus, Staphylococcus } \\
\text { simulans Staphylococcus argenteus } \\
\text { Staphylococcus pseudintermedius }\end{array}$ & $\begin{array}{l}\text { Staphylococcus phage SA75 Staphylococcus } \\
\text { phage SA13 }\end{array}$ \\
\hline S11 & Phage capsid protein & M*AEETNSNVTEETEVNE & $\begin{array}{l}\text { Staphylococcus, aureus Staphylococcus } \\
\text { spp. }\end{array}$ & \\
\hline S4 & $\begin{array}{l}\text { Phage encoded } \\
\text { lipoprotein }\end{array}$ & IHDKELDDPSEEESKLTQEEENSI & $\begin{array}{c}\text { Staphylococcus aureus, Staphylococcus } \\
\text { capitis, Staphylococcus epidermidis, } \\
\text { Staphylococcus cohnii, Staphylococcus } \\
\text { haemolyticus }\end{array}$ & Staphylococcus phage SPbeta-like \\
\hline S2 & $\begin{array}{c}\text { Phage head } \\
\text { morphogenesis protein }\end{array}$ & KDVQRIVSHVT & $\begin{array}{l}\text { Staphylococcus aureus } \\
\text { Staphylococcus argenteus }\end{array}$ & \\
\hline S9 & $\begin{array}{l}\text { YhgE/Pip, Phage } \\
\text { infection protein }\end{array}$ & $\begin{array}{l}\text { LNEYM*PNIEKLLN } \\
\text { VASNDIPAQFPK }\end{array}$ & $\begin{array}{c}\text { Staphylococcusaureus, Staphylococcus } \\
\text { haemolyticus Staphylococcus sp. } \\
\text { HMSC34C02 }\end{array}$ & \\
\hline S14 & Minor structural protein & KTTSEALKEVLSDT & Staphylococcus aureus & \\
\hline S4 & Phage portal protein & $\begin{array}{l}\text { EPKPVDATGADDPLKPDDRM* } \\
\text { ITNFHANLVDQKVSY }\end{array}$ & Staphylococcus aureus & \\
\hline
\end{tabular}


Table 1. Cont.

\begin{tabular}{|c|c|c|c|c|}
\hline Strain & Protein & Peptide & $\begin{array}{l}\text { Bacteria with } 100 \% \text { Homology Based } \\
\text { on the NCBI Protein Database }\end{array}$ & $\begin{array}{c}\text { Phages with } 100 \% \text { Homology Based on the } \\
\text { NCBI Protein Database }\end{array}$ \\
\hline S5 & Phage protein & VHISEFKYPLYM*DFLGTKGELE & $\begin{array}{c}\text { Staphylococcusaureus } \\
\text { Staphylococcus haemolyticus }\end{array}$ & \\
\hline S15 & Phage protein & MSHNALTTGIGIGAGAG & Staphylococcus aureus & \\
\hline S2 & Phage protein & EITDGEISSVLTM* ${ }^{*}{ }^{*}$ & $\begin{array}{l}\text { Staphylococcus aureus, Staphylococcus } \\
\text { hominis Staphylococcus epidermidis }\end{array}$ & \\
\hline $\mathrm{S} 20$ & $\begin{array}{l}\text { Phage recombination } \\
\text { protein Bet }\end{array}$ & KSSTTYEVNGETVK & $\begin{array}{c}\text { Staphylococcus aureus, Staphylococcus } \\
\text { sciuri }\end{array}$ & \\
\hline S2 & $\begin{array}{l}\text { Phage resistance } \\
\text { protein }\end{array}$ & ESVDTGEITANTTRTVK & $\begin{array}{c}\text { Staphylococcus aureus Staphylococcus } \\
\text { fleurettii } \\
\text { Staphylococcus pasteuri } \\
\text { Staphylococcus epidermidis } \\
\text { Staphylococcus warneri Staphylococcus } \\
\text { schleiferi Escherichia coli }\end{array}$ & \\
\hline $\mathrm{S} 13$ & $\begin{array}{l}\text { Tail tape measure } \\
\text { protein }\end{array}$ & GM*PTGTNVYAVKGGIADK & $\begin{array}{l}\text { Staphylococcus aureus, Staphylococcus } \\
\text { saprophyticus, Staphylococcus } \\
\text { pseudoxylosus }\end{array}$ & $\begin{array}{c}\text { Staphylococcus phage phiSa2wa_st } 5 \\
\text { Staphylococcus phage phi3A Staphylococcus phage } \\
\text { SH-St 15,644 Staphylococcus virus } 3 a\end{array}$ \\
\hline $\mathrm{S} 3$ & $\begin{array}{l}\text { Tail tape measure } \\
\text { protein }\end{array}$ & $\begin{array}{l}\text { VQHPGKLVNKVM* }^{*} \\
\text { SGLNINFGGGANATAK }\end{array}$ & Staphylococcus aureus & \\
\hline S4 & $\begin{array}{l}\text { Tail tape measure } \\
\text { protein }\end{array}$ & $\begin{array}{l}\text { QM*MEGLSGVMDLAAVSGEDLG } \\
\text { AVSDIVTDGLTAFGLKAKDSG }\end{array}$ & Staphylococcus aureus & \\
\hline S2 & $\begin{array}{l}\text { Tail tape measure } \\
\text { protein }\end{array}$ & AEEAGVTVKQL & $\begin{array}{c}\text { Staphylococcus aureus } \\
\text { Staphylococcus cohnii } \\
\text { Staphylococcus sp. HMSC061H04 } \\
\text { Staphylococcus hominis } \\
\text { Staphylococcus capitis } \\
\text { Staphylococcus cohnii } \\
\text { Staphylococcus sp. HMSC061H04 } \\
\text { Staphylococcus sp. HMSC067G10 } \\
\text { Staphylococcus } \\
\text { Staphylococcus haemolyticus } \\
\text { Enterococcus faecium } \\
\text { Staphylococcus epidermidis } \\
\text { Staphylococcus sp. HMSC067G10 } \\
\text { Staphylococcus haemolyticus } \\
\text { Enterococcus faecium } \\
\text { Staphylococcus epidermidis }\end{array}$ & Staphylococcus phage SPbeta-like \\
\hline $\mathrm{S} 10$ & $\begin{array}{l}\text { Phage repressor, } \\
\text { Cro/CI family }\end{array}$ & QKNVLNYANEQLDEQNKV & $\begin{array}{c}\text { Staphylococcus aureus, Bacilli, } \\
\text { Staphylococcus hyicus Staphylococcus } \\
\text { epidermidis }\end{array}$ & $\begin{array}{l}\text { Staphylococcus virus phiNM2 Staphylococcus } \\
\text { virus } 53 \text { Staphylococcus virus 80alpha }\end{array}$ \\
\hline $\mathrm{S} 13$ & Phage protein & KSNVEAFSNAVK & Staphylococcus aureus & $\begin{array}{l}\text { Staphylococcus virus 80alpha Staphylococcus } \\
\text { virus phiNM1 Staphylococcus virus phiNM2 }\end{array}$ \\
\hline S11 & Phage protein & PYHDLSDERIM*EELKK & $\begin{array}{l}\text { Staphylococcus aureus Staphylococcus } \\
\text { argenteus taphylococcus schweitzeri }\end{array}$ & $\begin{array}{l}\text { Staphylococcus virus phiETA2 Staphylococcus } \\
\text { phage P630 Staphylococcus virus SAP26 } \\
\text { Staphylococcus phage B236 Staphylococcus virus } \\
\text { 88 Staphylococcus prophage phiPV83 }\end{array}$ \\
\hline S4 & $\begin{array}{l}\text { Minor structural } \\
\text { protein }\end{array}$ & LNDNISNINTIV & $\begin{array}{c}\text { Pseudomonas aeruginosa } \\
\text { E. coli } \\
\text { Pararheinheimera mesophila } \\
\text { Staphylococcus pseudintermedius } \\
\text { Staphylococcus epidermidis, } \\
\text { Staphylococcus sp. KY49P Staphylococcus } \\
\text { argenteus Staphylococcus schleiferi } \\
\text { Staphylococcus hyicus Staphylococcus sp. } \\
\text { HMSC063H12 Staphylococcus aureus }\end{array}$ & $\begin{array}{c}\text { Staphylococcus virus 77 } \\
\text { Staphylococcus phage P630 } \\
\text { Staphylococcus phage SA780ruMSSAST101 } \\
\text { Staphylococcus phage phiSa119 } \\
\text { Staphylococcus phage phiN315 } \\
\text { Staphylococcus phage SA7 } \\
\text { Staphylococcus phage JS01 } \\
\text { Staphylococcus phage StauST398-4 } \\
\text { Staphylococcus virus 13 } \\
\text { Staphylococcus phage 23MRA } \\
\text { Staphylococcus virus 108PVL } \\
\text { Staphylococcus phage phiBU01 } \\
\text { Staphylococcus phage PVL } \\
\text { Staphylococcus phage tp310-1 } \\
\text { Staphylococcus phage P954 } \\
\text { Staphylococcus phage SA345ruMSSAST8 } \\
\text { Staphylococcus phage phiNM3 } \\
\text { Staphylococcus virus 77 } \\
\text { Staphylococcus phage phiSa2wa_st22 } \\
\text { Staphylococcus phage SA1014ruMSSAST7 } \\
\text { Staphylococcus phage P282 } \\
\text { Staphylococcus prophage phiPV83 } \\
\text { Staphylococcus phage 3 AJ-2017 } \\
\text { Staphylococcus phage SAP090B } \\
\text { Staphylococcus phage IME1346_01 } \\
\text { Staphylococcus phage phi5967PVL } \\
\text { Staphylococcus phage P1105 } \\
\text { Staphylococcus phage IME1361_01 }\end{array}$ \\
\hline
\end{tabular}


Table 1. Cont

\begin{tabular}{|c|c|c|c|c|}
\hline Strain & Protein & Peptide & $\begin{array}{c}\text { Bacteria with } 100 \% \text { Homology Based on } \\
\text { the NCBI Protein Database }\end{array}$ & $\begin{array}{l}\text { Phages with } 100 \% \text { Homology Based on the } \\
\text { NCBI Protein Database }\end{array}$ \\
\hline S9 & $\begin{array}{l}\text { PhiETA ORF58-like } \\
\text { protein }\end{array}$ & $\begin{array}{l}\text { GMVASMQMQVVQVNVLTM* } \\
\text { ELAQQNAMLTQQLTELK }\end{array}$ & Staphylococcus aureus & \\
\hline S4 & Phage portal protein & TEQLPRLEML & $\begin{array}{c}\text { Staphylococcus aureus, Staphylococcus sp. } \\
\text { HMSC063A07, Staphylococcus } \\
\text { lugdunensis, Staphylococcus sp. } \\
\text { HMSC068D08, Staphylococcus sp. } \\
\text { HMSC069E09 }\end{array}$ & \\
\hline S4 & Prophage, terminase & KDRYSSVSY & $\begin{array}{l}\text { Staphylococcus aureus, Staphylococcus } \\
\text { delphini, Staphylococcus pseudintermedius, } \\
\text { Staphylococcus agnetis, Staphylococcus } \\
\text { epidermidis, Staphylococcus hominis, } \\
\text { Staphylococcus haemolyticus, Paenibacillus } \\
\text { sophorae }\end{array}$ & Staphylococcus phage SPbeta-like \\
\hline S4 & $\begin{array}{l}\text { Prophage tail domain; } \\
\text { Peptidase }\end{array}$ & VLEM*IFLGEDPK & $\begin{array}{l}\text { Staphylococcus aureus } \\
\text { E. coli } \\
\text { Bacilli }\end{array}$ & $\begin{array}{c}\text { Staphylococcus phage phi7401PVL } \\
\text { Staphylococcus phage phiSa2wa_st121mssa } \\
\text { Staphylococcus virus 3a } \\
\text { Staphylococcus virus phiSLT } \\
\text { Staphylococcus phage tp310-2 } \\
\text { Staphylococcus phage } \\
\text { SA137ruMSSAST121PVL } \\
\text { Staphylococcus phage phiSa2wa_st5 } \\
\text { Staphylococcus phage phiSa2wa_st1 } \\
\text { Staphylococcus phage SH-St 15644 } \\
\text { Staphylococcus phage phi2958PVL } \\
\text { Staphylococcus virus IPLA35 } \\
\text { Staphylococcus phage P240 } \\
\text { Staphylococcus phage vB_SauS_JS02 } \\
\text { Staphylococcus virus 42e } \\
\text { Staphylococcus virus phi12 } \\
\text { Staphylococcus phage phiSa2wa_st72 } \\
\text { Staphylococcus phage vB_SauS_fPfSau02 } \\
\text { Staphylococcus phage phiSa2wa_st30 } \\
\text { Staphylococcus phage vB_SauS_phi2 } \\
\text { Staphylococcus phage StauST398-2 }\end{array}$ \\
\hline S15 & Site-specific integrase & VEELEDSEIHKK & $\begin{array}{l}\text { Staphylococcus aureus, Staphylococcus } \\
\text { epidermidis Staphylococcus haemolyticus } \\
\text { Staphylococcus condimenti Staphylococcus } \\
\text { sp. HMSC035D11 Staphylococcus warneri }\end{array}$ & $\begin{array}{l}\text { uncultured Caudovirales phage } \\
\text { Sequence ID: ASN72447.1 }\end{array}$ \\
\hline S13 & Site-specific integrase & KEAGSIINLHTINNALKSAC*R & Staphylococcus aureus Staphylococcus sp. & \\
\hline S6 & Site-specific integrase & YLNRNFVFTNHK & $\begin{array}{c}\text { Staphylococcus aureus, Staphylococcus } \\
\text { argenteus Staphylococcus cohini } \\
\text { Staphylococcus lugdunensis } \\
\text { Staphylococcus caeli Staphylococcus sp. } 47.1\end{array}$ & \\
\hline S9 & $\begin{array}{l}\text { Terminase large } \\
\text { subunit }\end{array}$ & KAMIKASPK & $\begin{array}{c}\text { Staphylococcusaureus } \\
\text { Escherichia coli } \\
\text { Staphylococcus sp. HMSC74F04 } \\
\text { Staphylococcus sp. HMSC055H07 } \\
\text { Cutibacterium acnes Staphylococcus warneri } \\
\text { Brevibacillus laterosporus } \\
\text { Bacillus cihuensis } \\
\text { Paenibacillus larvae }\end{array}$ & $\begin{array}{c}\text { Staphylococcus phage vB_SauS_JS02 } \\
\text { Staphylococcus phage } \\
\text { Staphylococcus phage phiSa2wa_st5 } \\
\text { Staphylococcus phage LH1 } \\
\text { Staphylococcus phage phiSa2wa_st1 } \\
\text { Staphylococcus phage phiSa2wa_st121mssa } \\
\text { Staphylococcus virus IPLA35 } \\
\text { Staphylococcus phage tp310-2 } \\
\text { Staphylococcus virus phiSLT } \\
\text { Staphylococcus phage StauST398-2 } \\
\text { Staphylococcus phage vB_SauS_phi2 } \\
\text { Staphylococcus virus phi12 } \\
\text { Staphylococcus phage SMSAP5 } \\
\text { Staphylococcus phage phi2958PVL } \\
\text { Staphylococcus virus 3a } \\
\text { Staphylococcus phage YMC/09/04/R1988 }\end{array}$ \\
\hline S20 & $\begin{array}{l}\text { Phage repressor, } \\
\text { Cro/CI family }\end{array}$ & RIQQLADYFNVPK & $\begin{array}{c}\text { Staphylococcus aureus Staphylococcus } \\
\text { pettenkoferi Staphylococcus pettenkoferi } \\
\text { Staphylococcus capitis Staphylococcus } \\
\text { devriesei }\end{array}$ & $\begin{array}{l}\text { Staphylococcus phage vB_SauS_phi2 } \\
\text { Staphylococcus virus IPLA35 }\end{array}$ \\
\hline
\end{tabular}


Table 1. Cont.

\begin{tabular}{|c|c|c|c|c|}
\hline Strain & Protein & Peptide & $\begin{array}{l}\text { Bacteria with } 100 \% \text { Homology Based on } \\
\text { the NCBI Protein Database }\end{array}$ & $\begin{array}{l}\text { Phages with } 100 \% \text { Homology Based on the } \\
\text { NCBI Protein Database }\end{array}$ \\
\hline S4 & $\begin{array}{l}\text { Transposase B from } \\
\text { transposon Tn554 O }\end{array}$ & WDRRNLPLPDDK & $\begin{array}{c}\text { Staphylococcus aureus, } \\
\text { Staphylococcuspettenkoferi } \\
\text { Staphylococcushominis, Quasibacillus } \\
\text { thermotolerans } \\
\text { Staphylococcaceae } \\
\text { Staphylococcusvitulinus } \\
\text { Streptococcus suis } \\
\text { Staphylococcusfelis } \\
\text { Salinicoccus roseus } \\
\text { Staphylococcus epidermidis } \\
\text { Staphylococcus lentus } \\
\text { Staphylococcus warneri } \\
\text { Staphylococcus epidermidis } \\
\text { Staphylococcus chromogenes } \\
\text { Staphylococcus sp. HMSC058E01 } \\
\text { Enterococcus faecium } \\
\text { Staphylococcus epidermidis VCU065 } \\
\text { Staphylococcus cohnii } \\
\text { Negativicoccus succinicivorans } \\
\text { Eubacteriaceae bacterium } \\
\text { Staphylococus } \\
\text { Enterococcus faecium } \\
\text { Enterococcus } \\
\text { Staphylococcus fleurettii } \\
\text { Staphylococcus sp. } 47.1 \\
\text { Bacilli } \\
\text { Staphylococcus sp. SKL71207 } \\
\text { Lactobacillales }\end{array}$ & \\
\hline $\mathrm{S} 13$ & $\begin{array}{l}\text { Uncharacterized } \\
\text { phage protein }\end{array}$ & $\mathrm{C}^{*}$ VSGIAGGAVTGGTTLGLAGAG & $\begin{array}{c}\text { Staphylococcus aureus Staphylococcus } \\
\text { argenteus } \\
\text { Staphylococcus schweitzeri } \\
\text { Staphylococcus schweitzeri } \\
\text { Staphylococcus hyicus } \\
\text { Staphylococcus agnetis }\end{array}$ & \\
\hline $\mathrm{S} 13$ & $\begin{array}{l}\text { Uncharacterized } \\
\text { phage protein }\end{array}$ & DIITVYC*PENGTATDEY & Staphylococcus aureus & \\
\hline S20 & $\begin{array}{l}\text { Uncharacterized } \\
\text { phage protein }\end{array}$ & QTDVPSWVPM*VLR & $\begin{array}{c}\text { Staphylococcusaureus Staphylococcus sp. } \\
\text { HMSC74F04 } \\
\text { Bacilli } \\
\text { Staphylococcus } \\
\text { Staphylococcus argenteus } \\
\text { Staphylococcus sp. HMSC063H12 }\end{array}$ & \\
\hline S12 & $\begin{array}{l}\text { Uncharacterized } \\
\text { phage protein }\end{array}$ & IIINHDEIDLL & $\begin{array}{l}\text { Staphylococcus aureus Staphylococcus } \\
\text { epidermidis } \\
\text { Staphylococcus hominis } \\
\text { Staphylococcus haemolyticus } \\
\text { Staphylococcus sp. HMSC067G10 } \\
\text { Staphylococcus haemolyticus } \\
\text { Staphlococus epidermidis } \\
\text { Staphylococcus petrasii } \\
\text { Staphylococcus capitis }\end{array}$ & Staphylococcus phage SPbeta-like \\
\hline S14 & $\begin{array}{l}\text { Uncharacterized } \\
\text { phage protein }\end{array}$ & TSIELITGFTK & $\begin{array}{c}\text { Staphylococcus aureus, Staphylococcus sciuri, } \\
\text { Staphylococcus schweitzeri, Staphylococcus } \\
\text { spp. }\end{array}$ & $\begin{array}{l}\text { Staphylococcus phage phi879, Staphylococcus } \\
\text { phage phi575, Staphylococcus phage PVL, } \\
\text { Staphylococcus prophage phiPV83, } \\
\text { Staphylococcus phage SA45ruMSSAST97 }\end{array}$ \\
\hline S3 & $\begin{array}{l}\text { Uncharacterized } \\
\text { phage protein }\end{array}$ & EFRNKLNELGADK & $\begin{array}{l}\text { Staphylococcusaureus, Streptococcus } \\
\text { pneumoniae, Terrabacteria group }\end{array}$ & $\begin{array}{c}\text { Staphylococcus phage phi7401PVL, } \\
\text { Staphylococcus phage tp310-2, Staphylococcus } \\
\text { phage vB_SauS_phi2, Staphylococcus virus } \\
\text { IPLA35, Staphylococcus phage } \\
\text { phiSa2wa_st30, Staphylococcus virus } 47 \text {, } \\
\text { Staphylococcus virus } 3 a\end{array}$ \\
\hline S3 & $\begin{array}{l}\text { Phage repressor, } \\
\text { Cro/CI family }\end{array}$ & HLEEVDIR & $\begin{array}{l}\text { Staphylococcusaureus, Paxillus involutus } \\
\text { ATCC 200175, Brassica cretica, } \\
\text { Staphylococcus epidermidis, Staphylococcus } \\
\text { spp., Enterobacter hormaechei }\end{array}$ & \\
\hline S4 & $\begin{array}{l}\text { YhgE/Pip; Phage } \\
\text { infection protein }\end{array}$ & APQSTSVKK & $\begin{array}{c}\text { Staphylococcusaureus, } \\
\text { Staphylococcusschweitzeri, Staphylococcus } \\
\text { sp. }\end{array}$ & \\
\hline S4 & $\begin{array}{l}\text { YhgE/Pip Phage } \\
\text { infection protein }\end{array}$ & ALNFAADDVPAQFPK & $\begin{array}{l}\text { S. aureus, Staphylococcus sp. HMSC36A10, } \\
\text { Staphylococcus sp. HMSC34H10, } \\
\text { Pseudomonas aeruginosa, E. coli }\end{array}$ & \\
\hline
\end{tabular}




\subsection{Phage Peptides Determined from the Analyzed S. aureus Strains}

For strains S2 and S3, six and three phage peptides were determined, respectively. For strain S4, seventeen phage peptides were determined, and three phage peptides were determined for strain S5. For strains S6 and S7, three and one phage peptides were determined, respectively. Moreover, for strains S8 and S9, two phage peptides and seven phage peptides were determined. For strains S10 and S11, five and three phage peptides were determined, respectively. For strains S12 and S13, five phage peptides and six phage peptides were determined, respectively. For strains S14 and S15, four and two phage peptides were determined, respectively. For strain S16, three phage peptides were determined, and one phage peptide was determined for strain S17. For strains S18 and S19, one phage peptide each was determined. Finally, for strain S20, seven phage peptides were determined.

A large number of phage peptides from structural proteins were identified (Table 1). Peptides from proteins such as the major capsid protein, major tail protein, minor structural protein, phage head morphogenesis protein, tail tape measure protein and phage tail fiber protein were determined. Moreover, different phage peptides from the major capsid protein and tail protein were determined (Table 1). Identifying these phage peptides is reasonable, as the major capsid protein and major tail protein are the most abundant proteins in mature virions [6].

There are a large number of uncharacterized protein sequences in databases, and more than $20 \%$ of all protein domains are annotated as "domains of unknown function" (DUFs). Several uncharacterized phage proteins and DUFs from Staphylococcus bacteriophages were identified for the analyzed strains (Table 1) [43,44].

Different peptides from repressor-type Cro/CI were determined. For strains S11 and S20 (both potential enterotoxin C producers), the same phage peptides of repressor-type Cro/CI were identified (Table 1). CI and Cro are encoded in the lysogeny module of lambdoid bacteriophages, particularly $\lambda$ bacteriophages. Together, CII and CIII (that are formed through the anti-terminator role of protein $\mathrm{N}$ ) act as an inducer that favors the first expression of the $c I$ gene from the appropriate promoter; if the CI repressor predominates, the phage remains in the lysogenic state, but if the Cro predominates, the phage transitions into the lytic cycle, helped by the late $Q$ regulator. The xenobiotic XRE regulator is extended in bacteria and has similarity to the Cro $\lambda$ repressor, exhibiting a helix-turn-helix $(\mathrm{HTH})$ conformation [45]. Peptides of the CI/Cro-repressor types are usually named XRE family proteins in the NCBI database for bacteria.

Three phage peptides of the complement inhibitor were identified (Table 1). Staphylococcal complement inhibitors are involved in the evasion of human phagocytosis by blocking C3 convertases, and a study reported that complement inhibitor genes were also found in staphylococcal phages [46]. Another autolysin was determined in the present results, an $\mathrm{N}$-acetylmuramoyl-L-alanine amidase that plays a role in bacterial adherence to eukaryotic cells [19]. The phage protein NrdI, which is a type of ribonucleotide reductase (RNR), was also identified. Several peptides of transposases, integrases and terminases were identified along with a DNA primase phage associated protein and a DNA phage binding protein. Moreover, peptides of other proteins, such as GNAT family N-acetyltransferase, holin, peptidase, methylase, anti-repressor protein (Ant), phage-resistant protein, phage-encoded lipoprotein, phage infection protein, phage portal protein, toxin phage proteins associated with pathogenicity islands and a protein involved in fibrinogen-binding proteins, were identified. A PBSX family phage terminase peptide was determined, and this protein is involved in double-stranded DNA binding, DNA packaging and endonuclease and ATPase activities [47].

As shown in Table 1, the vast majority of phage-specific peptides are not specific to S. aureus and can be found in other species of Staphylococcus. As an exception, the same peptides, such as peptide LLHALPTGNDSGGDKLLPK from a major capsid protein, were also found in Streptococcus pneumoniae, and peptide AYINITGLGFAK from a major tail protein was also found in Pararheinheimera mesophila; whether these examples represent 
direct recombinations between bacteria belonging to different families or whether phagemediated recombination occurs remains to be elucidated. Furthermore, as mentioned before, eighteen identified peptides were very specific for $S$. aureus based on the NCBI database (see Figure S1).

\subsection{Staphylococcus spp. Phage Genome Comparisons and Their Relatedness}

A phylogenomic tree of Staphylococcus spp. phages from the NCBI database (accession numbers in Table S2 in Supplemental Data 2) with 100\% similarity to those found in this study was built (Figure 2). The phages identified in this study were classified in the order Caudovirales and the family Siphoviridae. Many of these bacteriophages were classified into the genera Phietavirus, Biseptimavirus, Triavirus phieta-like virus, SPbeta-like virus and unclassified genera. Genomes of well-known phages of the families Siphoviridae, Myoviridae and Podoviridae, such as phage Lambda, T4 and T7, respectively, were added for comparison purposes. The genome analysis showed three well-defined clusters that mainly divided the phylogenomic tree into different phage genera (Phietavirus, Biseptimavirus and Triavirus). Two principal branches separated Clusters A, B and C from D. Cluster A was formed by Staphylococcus Phietavirus, two phieta-like viruses and two unclassified Staphylococcus phages. Cluster B was formed by Staphylococcus phages classified as Biseptimavirus and by one unclassified Staphylococcus phage. Cluster C was formed by enterobacterial bacteriophages and one SPbeta-like virus. Finally, cluster D was formed by Triavirus Staphylococcus phages and two unclassified Staphylococcus phages. To the best of our knowledge, this is the first time that phages from mastitis-causing staphylococci were grouped in a phylogenomic tree.

Specific peptides were found in related Staphylococcus spp. phages (Table 2) located closely in the phylogenomic tree (Figure 2). Peptides HAGYVRC*KLF and MPVYKDGNTGKWYFSI were found in phages of cluster A. Furthermore, peptides IYDRNSDTLDGLPVVNLK, QKNVLNYANEQLDEQNKV, EVPNEPDYIVIDVC*EDYSASK, KSNVEAFSNAVK and KLYIIEEYVKQGM were found in Staphylococcus phages of the A.1 subbranch in cluster A. Additionally, peptide AVAELLKEINR was found in phages of the A.2 branch. The peptide AYINITGLGFAK was found in phages of cluster B.1, and TSIELITGFTK was found in phages of cluster B.2. Peptides VSYTLDDDDFITDVETAK and LLHALPTGNDSGGDKLLPK, which belong to the phage major capsid protein, were found in the same 14 Staphylococcus phages of cluster D. Peptides ELAEAIGVSQPTVSNWIQQTK and IQQLADYFNVPK, which belong to the phage-repressor Cro/CI family of proteins, were found in the same bacteriophages of cluster D. Moreover, peptides LYVGVFNPEATK, RVSYTLDDDDFITDVETAKELKL LYVGVFNPEATK, VLEMIFLGEDPK, KAMIKASPK, EFRNKLNELGADK and GMPTGTNVYAVKGGIADK were also found in phages of cluster D. Peptides IHDKELDDPSEEESKLTQEEENSI, IIINHDEIDLL, KDRYSSVSY and AEEAGVTVKQL are specific to Staphylococcus phage SPbeta-like.

Table 2. Phage biomarker peptides that belong to bacteriophages and phylogenomic tree clusters. Relationships between specific phage biomarker peptides and phylogenomic tree clusters.

\begin{tabular}{|c|c|c|c|}
\hline Protein & Peptide & Phages & Cluster Located \\
\hline Major capsid protein & VSYTLDDDDFITDVETAK & $\begin{array}{c}\text { Staphylococcus phage phiSa2wa_st72 } \\
\text { Staphylococcus phage tp310-2 } \\
\text { Staphylococcus phage phiSa2wa_st121mssa } \\
\text { Staphylococcus phage vB_SauS_phi2 } \\
\text { Staphylococcus phage StauST398-2 } \\
\text { phage phiSa2wa_st30 } \\
\text { Staphylococcus virus 3a Staphylococus phage LH1 Staphylococcus } \\
\text { Staphylococcus virus phi12 Staphylococcus virus phiSLT } \\
\text { Staphylococcus phage vB_SauS_JS02 } \\
\text { Staphylococcus phage R4 } \\
\text { Staphylococcus phage vB_SauS_fPfSau02 } \\
\text { Staphylococcus phage SA137ruMSSAST121PVL }\end{array}$ & Cluster D \\
\hline
\end{tabular}


Table 2. Cont.

\begin{tabular}{|c|c|c|c|}
\hline Protein & Peptide & Phages & Cluster Located \\
\hline Major capsid protein & LLHALPTGNDSGGDKLLPK & $\begin{array}{c}\text { Staphylococcus phage phiSa2wa_st72 } \\
\text { Staphylococcus phage phiSa2wa_st121mssa } \\
\text { Staphylococcus phage vB_SauS_phi2 } \\
\text { Staphylococcus phage StauST398-2 } \\
\text { Staphylococcus virus phi12 } \\
\text { Staphylococcus virus } 3^{\mathrm{a}} \\
\text { Staphylococcus virus phiSLT } \\
\text { Staphylococcus phage tp310-2 } \\
\text { Staphylococcus phage vB_SauS_JS02 } \\
\text { Staphylococcus phage R4 } \\
\text { Staphylococcus phage vB_SauS_fPfSau02 } \\
\text { Staphylococcus phage SA137ruMSSAST121PVL }\end{array}$ & Cluster D \\
\hline Major capsid protein & RVSYTLDDDDFITDVETAKELKL & $\begin{array}{c}\text { Staphylococcus phage LH1 } \\
\text { Staphylococcus phage StauST398-2 } \\
\text { Staphylococcus phage vB_SauS_phi2 } \\
\text { Staphylococcus phage R4 }\end{array}$ & Cluster D \\
\hline Major tail protein & LYVGVFNPEATK & $\begin{array}{l}\text { Staphylococcus phage vB_SauS_phi2 } \\
\text { Staphylococcus virus phi12 } \\
\text { Staphylococcus virus phiSLT } \\
\text { Staphylococcus phage R4 } \\
\text { Staphylococcus phage vB_SauS_JS02 } \\
\text { Staphylococcus phage SH-St } 15644 \\
\text { Staphylococcus virus } 3 \mathrm{a} \\
\text { Staphylococcus phage P240 }\end{array}$ & Cluster D \\
\hline $\begin{array}{l}\text { Phage repressor, Cro/CI } \\
\text { family }\end{array}$ & ELAEAIGVSQPTVSNWIQQTK & $\begin{array}{c}\text { Staphylococcus virus IPLA35 } \\
\text { Staphylococcus phage SMSAP5 } \\
\text { Staphylococcus phage vB_SauS_phi2 }\end{array}$ & Cluster D \\
\hline $\begin{array}{l}\text { Phage repressor, Cro/CI } \\
\text { family }\end{array}$ & IQQLADYFNVPK & $\begin{array}{c}\text { Staphylococcus virus IPLA35 } \\
\text { Staphylococcus phage SMSAP5 } \\
\text { Staphylococcus phage vB_SauS_phi2 }\end{array}$ & Cluster D \\
\hline
\end{tabular}

\begin{tabular}{|c|c|c|c|}
\hline Major tail protein & AYINITGLGFAK & $\begin{array}{c}\text { Staphylococcus phage phiNM3 Staphylococcus phage StauST398-4 } \\
\text { Staphylococcus phage P282 } \\
\text { Staphylococcus phage phiN315 } \\
\text { Staphylococcus phage phi7247PVL } \\
\text { Staphylococcus phage phiSa2wa_st22 Staphylococcus virus } 77 \\
\text { Staphylococcus phage P954 }\end{array}$ & Cluster B.1 \\
\hline Major capsid protein & IYDRNSDTLDGLPVVNLK & $\begin{array}{c}\text { Staphylococcus virus } 85 \text { Staphylococcus phage SP5 } \\
\text { Staphylococcus virus phiETA2 } \\
\text { Staphylococcus phage phiNM } \\
\text { Staphylococcus virus SAP26 } \\
\text { Staphylococcus phage SA12 } \\
\text { Staphylococcus virus Baq Sau1 }\end{array}$ & Cluster A.1 \\
\hline $\begin{array}{l}\text { Uncharacterized phage } \\
\text { protein }\end{array}$ & AVAELLKEINR & $\begin{array}{c}\text { Staphylococcus virus } 71 \text { Staphylococcus virus } 55 \text { Staphylococcus } \\
\text { virus } 88\end{array}$ & Cluster A.2 \\
\hline $\begin{array}{l}\text { DUF2479, Phage tail } \\
\text { fiber, BppU family } \\
\text { phage baseplate upper } \\
\text { protein }\end{array}$ & HAGYVRCKLF & $\begin{array}{c}\text { Staphylococcus phage SA97 } \\
\text { Staphylococcus virus } 55 \\
\text { Staphylococcus virus } 80 \\
\text { Staphylococcus virus phiETA3 } \\
\text { uncultured Caudovirales phage Staphylococus virus } 85 \\
\text { Staphylococcus virus phiETA2 Staphylococcus phage 55-2 } \\
\text { Staphylococcus phage B166 Staphylococcus phage B236 } \\
\text { Staphylococcus virus SAP26 Staphylococcus virus } 88 \text { Staphylococcus } \\
\text { virus phiETA Staphylococcus virus } 11 \text { Staphylococcus phage SP5 } \\
\text { Staphylococcus virus } 69 \text { Staphylococcus phage ROSA } \\
\text { Staphylococcus phage TEM123 Staphylococcus virus } 92 \\
\text { Staphylococcus phage StauST398-1 } \\
\text { Staphylococcus virus phiNM2 Staphylococcus virus phiNM1 } \\
\text { Staphylococcus virus } 29 \\
\text { Staphylococcus phage vB_SauS-SAP27 Staphylococcus virus } \\
\text { 80alpha Staphylococcus phage HSA84 } \\
\text { Staphylococcus virus phiMR11 } \\
\text { Staphylococcus phage SAP33 } \\
\text { Staphylococcus phage 3MRA }\end{array}$ & Cluster A \\
\hline Phage terminase & KLYIIEEYVKQGM & $\begin{array}{c}\text { Staphylococcus virus Baq_Sau1 Staphylococcus virus phiETA2 } \\
\text { Staphylococcus virus } 69 \text { Staphylococcus virus } 11 \\
\text { Staphylococcus virus 80alpha }\end{array}$ & Cluster A.1 \\
\hline $\begin{array}{l}\text { Phage-related cell wall } \\
\text { hydrolase; Peptidase } \\
\text { C51; CHAP domain- }\end{array}$ & EVPNEPDYIVIDVC*EDYSASK & $\begin{array}{l}\text { Staphylococcus virus IPLA88 Staphylococcus virus phiNM2 } \\
\text { Staphylococcus phage SAP40 Staphylococcus phage phi } 53 \\
\text { Staphylococcus virus phiNM4 Staphylococcus phage SA12 } \\
\text { Staphylococcus virus } 69 \text { Staphylococcus phage SA97 Staphylococcus } \\
\text { phage TEM123 Staphylococcus virus } 11 \text { Staphylococcus virus } \\
\text { phiMR25 Staphylococcus virus } 53 \text { Staphylococcus phage SAP33 }\end{array}$ & Cluster A.1 \\
\hline
\end{tabular}


Table 2. Cont.

\begin{tabular}{|c|c|c|c|}
\hline Protein & Peptide & Phages & Cluster Located \\
\hline $\begin{array}{l}\text { Prophage_tail domain-; } \\
\text { Peptidase }\end{array}$ & VLEM*IFLGEDPK & $\begin{array}{c}\text { Staphylococcus phage phi7401PVL } \\
\text { Staphylococcus phage phiSa2wa_st121mssa Staphylococcus virus } \\
\text { 3a } \\
\text { Staphylococcus virus phiSLT } \\
\text { Staphylococcus phage tp310-2 } \\
\text { Staphylococcus phage SA137ruMSSAST121PVL } \\
\text { Staphylococcus phage phiSa2wa_st5 } \\
\text { Staphylococcus phage phiSa2wa_st1 } \\
\text { Staphylococcus phage SH-St 15644 } \\
\text { Staphylococcus phage phi2958PVL } \\
\text { Staphylococcus virus IPLA35 } \\
\text { Staphylococcus phage P240 } \\
\text { Staphylococcus virus phi12 } \\
\text { Staphylococcus phage phiSa2wa_st72 } \\
\text { Staphylococcus phage vB_SauS_fPfSau02 } \\
\text { Staphylococcus phage phiSa2wa_st30 } \\
\text { Staphylococcus phage vB_SauS_phi2 } \\
\text { Staphylococcus phage StauST398-2 }\end{array}$ & Cluster D \\
\hline Terminase large subunit & KAM*IKASPK & $\begin{array}{c}\text { Staphylococcus phage vB_SauS_JS02 } \\
\text { Staphylococcus phage } \\
\text { Staphylococcus phage phiSa2wa_st5 } \\
\text { Staphylococcus phage LH1 } \\
\text { Staphylococcus phage phiSa2wa_st1 } \\
\text { Staphylococcus phage phiSa2wa_st121mssa } \\
\text { Staphylococcus virus IPLA35 } \\
\text { Staphylococcus phage tp310-2 } \\
\text { Staphylococcus virus phiSLT } \\
\text { Staphylococcus phage StauST398-2 } \\
\text { Staphylococcus phage vB_SauS_phi2 } \\
\text { Staphylococcus virus phi12 } \\
\text { Staphylococcus phage SMSAP5 } \\
\text { Staphylococcus phage phi2958PVLStaphylococcus virus 3a } \\
\text { Staphylococcus phage YMC/09/04/R1988 }\end{array}$ & Cluster D \\
\hline $\begin{array}{l}\text { Uncharacterized phage } \\
\text { protein }\end{array}$ & TSIELITGFTK & $\begin{array}{l}\text { Staphylococcus phage phi879, Staphylococcus phage phi575, } \\
\text { Staphylococcus phage PVL, Staphylococcus prophage phiPV83, } \\
\text { Staphylococcus phage SA45ruMSSAST97 }\end{array}$ & Cluster B2 \\
\hline $\begin{array}{l}\text { Uncharacterized phage } \\
\text { protein }\end{array}$ & EFRNKLNELGADK & $\begin{array}{c}\text { Staphylococcus phage phi7401PVL, Staphylococcus phage tp310-2, } \\
\text { Staphylococcus phage vB_SauS_phi2, Staphylococcus virus } \\
\text { IPLA35, Staphylococcus phage phiSa2wa_st30, Staphylococcus } \\
\text { virus } 47 \text {, } \\
\text { Staphylococcus virus 3a }\end{array}$ & Cluster D \\
\hline Phage protein & KSNVEAFSNAVK & $\begin{array}{l}\text { Staphylococcus virus 80alpha Staphylococcus virus phiNM1 } \\
\text { Staphylococcus virus phiNM2 }\end{array}$ & Cluster A.1 \\
\hline $\begin{array}{l}\text { Phage repressor, } \mathrm{Cro} / \mathrm{CI} \\
\text { family }\end{array}$ & QKNVLNYANEQLDEQNKV & $\begin{array}{c}\text { Staphylococcus virus phiNM2 Staphylococcus virus } 53 \\
\text { Staphylococcus virus 80alpha }\end{array}$ & Cluster A.1 \\
\hline $\begin{array}{l}\text { Tail tape measure } \\
\text { protein }\end{array}$ & GM*PTGTNVYAVKGGIADK & $\begin{array}{l}\text { Staphylococcus phage phiSa2wa_st5 Staphylococcus phage phi3A } \\
\text { Staphylococcus phage SH-St 15,644 Staphylococcus virus 3a }\end{array}$ & Cluster D \\
\hline integrase & M*PVYKDGNTGKWYFSI & $\begin{array}{c}\text { Staphylococcus phage B166 Staphylococcus virus phiMR25 } \\
\text { Staphylococcus virus } 88\end{array}$ & Cluster A \\
\hline
\end{tabular}

In addition, a correlation relating bacterial species for each cluster with all peptides found in the bacteriophages with $100 \%$ similarity was found. The results showed that clustered phages were related to specific species of Staphylococcus. All studied phages were found to be related to $S$. aureus; however, most of them were also found to be related to additional Staphylococcus species. S. argenteus was found to be related in all clusters of the phylogenomic tree. Cluster A phage peptides were found to be mainly related to $S$. simiae. However, different Staphylococcus species (S. xylosus, S. muscae, S. haemolyticus, S. simiae, S. sciuri, S. pseudintermedius, S. devriesei, S. warneri and S. capitis) were found to be related to phages of cluster D.

\subsection{Identification of Peptides of Virulence Factors}

In this work, 405 peptides from $S$. aureus were determined to be related to virulence factors (Excel dataset Supplemental Data). Among these peptides, proteins such as staphopain, beta-lactamase, elastin-binding protein peptides and a multidrug ATP-binding cassette $(\mathrm{ABC})$ transporter were identified. 


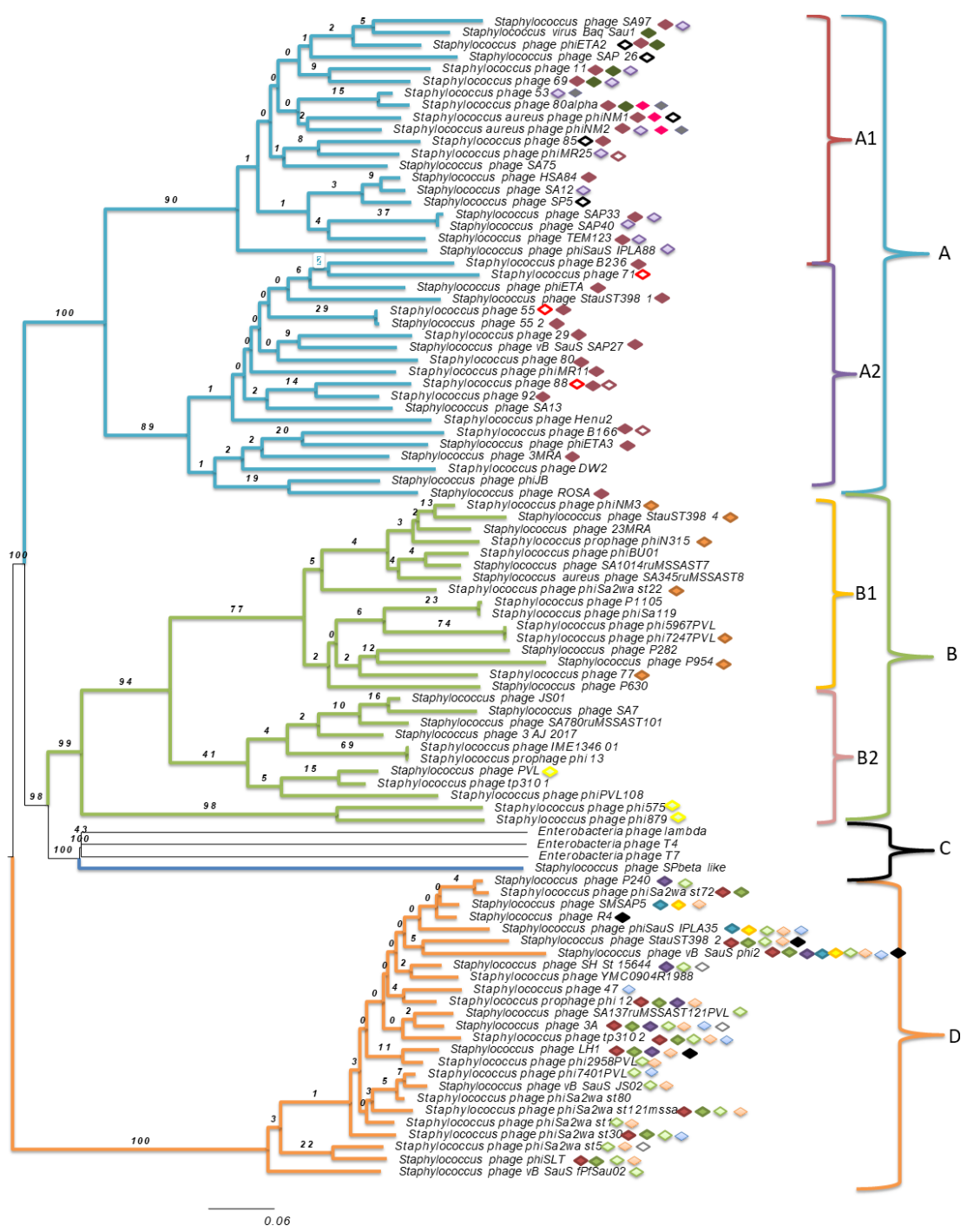

Figure 2. Phylogenomic tree generated by the Virus Classification and Tree Building Online Resource (VICTOR) using the complete genomic sequences of the determined Staphylococcus spp. phages. The access numbers of the determined phage genomes are shown in Table S2 in Supplemental Data 2. Genomes of the lambda (NC_001416.1), T4 (NC_000866.4) and T7 (NC_001604.1) phages were added for comparison purposes. The VICTOR phylogenetic tree construction was based on an intergenic distance analysis with the GBDP tool (Genome BLAST Distance Phylogeny). The significance of each branch is indicated by a pseudo-bootstrap value calculated as a percentage for 1000 subsets. Bar, 20 nt (nucleotides) substitutions per 100 nt. Clusters are represented by different colors: light blue, cluster A, red, cluster A.1, purple, cluster A.2, light green, cluster B, yellow, cluster B.1, pink, cluster B.2, black, cluster C and orange, cluster D. Specific cluster peptides are represented by different color forms: $>$, yellow-filled diamond IQQLADYFNVPK (cluster A-specific), $>$, brown-filled diamond HAGYVRCKLF (cluster A-specific), $\diamond$, black-outlined diamond IYDRNSDTLDGLPVVNLK (cluster A.1-specific), $\diamond$, red=outlined diamond AVAELLKEINR (cluster A.2-specific), $>$, pink-filled diamond KSNVEAFSNAVK (cluster A.1), $>$, gray-filled diamond QKNVLNYANEQLDEQNKV (cluster A.1), $\diamond$, brown-outlined diamond MPVYKDGNTGKWYFSI (cluster A-specific), $>$, dark gray-filled diamond KLYIIEEYVKQGM (cluster A.1-specific), $\diamond$, purple-outlined diamond EVPNEPDYIVIDVC*EDYSASK (cluster A.1-specific), $\diamond$, orange-filled diamond AYINITGLGFAK (cluster B.1-specific), $>$, yellow-outlined diamond TSIELITGFTK (cluster B.2-specific), $\diamond$, red-filled diamond VSYTLDDDDFITDVETAK (cluster D-specific), $\diamond$, green-filled diamond LLHALPTGNDSGGDKLLPK (cluster D-specific), > , black-filled diamond RVSYTLDDDDFITDVETAKELKL (cluster D-specific), $\diamond$, purple-filled diamond LYVGVFNPEATK (cluster D-specific, $\diamond$, blue-filled diamond ELAEAIGVSQPTVSNWIQQTK (cluster D-specific); $\diamond$, light green-filled diamond VLEMIFLGEDPK (cluster D-specific), $\diamond$, orange-outlined diamond KAMIKASPK (cluster D-specific) and $\diamond$, gray-outlined diamond GMPTGTNVYAVKGGIADK (cluster D-specific). 


\section{Discussion}

LC-MS/MS-based methods for bacteriophage identification offer several advantages compared with other approaches, since bacteriophages can be directly identified with this method without using genomic tools, which provides a new strategy for drawing the appropriate conclusions. In addition, the method proposed here may be applied for further analyses without the requirement of growing bacteria, since the samples can be collected directly from foodstuffs. The study of noninduced prophages provides a fast analysis and can detect specific temperate phage proteins produced by $S$. aureus while integrated in the bacterial genome or by phages that are infecting the bacteria. Both cases provide the identification of specific $S$. aureus species or strains-in this case, an S. aureus mastitis producer. In the proteomic repository of the 20 different $S$. aureus strains analyzed, 79 peptides from staphylococcal bacteriophages were identified. Among them, eighteen of these phage peptides were S. aureus-specific. As bacteriophages are host-specific, these putative diagnostic peptides could be good diagnostic biomarkers for the detection and characterization of S. aureus and S. aureus phages.

The results show that a given specific peptide is present in closely related phages (Table 2). These bacteriophage peptides can be used as specific markers to establish S. aureus bacteriophage relationships (Figure 2). Additionally, phages that show the same peptides and are specific to Staphylococcus spp. are located close to one another in the phylogenomic tree, suggesting that a link does exist between phage phylogeny and bacteriophages that can infect the same bacterial species.

The study shown here exemplifies how phylogenomic trees based on the genome analysis provide useful information, and the study corroborates previous investigations, which suggested that viral genomic or subgenomic region analyses provide the best tool for reconstructing viral evolutionary histories [48]. Nevertheless, the lack of knowledge of the phage genomic content [49] makes a phage analysis more difficult. The first priority must be the contribution of new large amounts of data for phages infecting bacteria [12].

In addition, there is an urgent need for novel therapies to treat and prevent mastitis [50]. Bacteriophage therapy is an alternative to the antibiotic treatment of bovine mastitis [51], with a high specificity and a low probability for bacterial resistance development [52]. Many studies have demonstrated the effectiveness of bacteriophages in a variety of animal models to fight several mastitis-causing pathogenic bacteria. Some studies have shown how virulent phages such as SPW and SA phages are active against bovine mastitis-associated S. aureus. Moreover, SAJK-IND and MSP phages have specific lytic activity against several strains of $S$. aureus isolated from mastitis milk samples [53]. Indeed, mouse-induced mastitis models decreased their bacterial counts after treatment with a vBSM-A1 and vBSP-A2 phage cocktail [54]. Finally, several temperate phage mixtures have been shown to be more effective than using a single temperate phage for inhibiting $S$. aureus. According to the data obtained for the different models of mastitis, phage therapy using bacteriophages in this study can be considered an innovative alternative to antibiotics for the treatment of mastitis caused by S. aureus.

Finally, the proteomic analysis by LC-ESI-MS/MS performed in this study provides relevant insights into the search for potential phage origin diagnostic peptide biomarkers for mastitis-causing $S$. aureus. In addition, this method may be useful for searching peptide biomarkers for the identification and characterization of mastitis-causing species and for finding new $S$. aureus phages useful as possible therapies for mastitis.

Supplementary Materials: The following are available online at https: / www.mdpi.com/article/ 10.3390/foods10040799/s1: Figure S1: MS/MS spectrums for S. aureus-specific peptide biomarkers. The corresponding peptides were tested for specificity using the BLASTp algorithm. Excel Dataset Supplemental Data 1: Complete nonredundant peptide dataset. Supplemental Data 2: Table S1: Staphylococcus aureus (SA) strains used in this study. Table S2: Linage, authors and accession number of studied bacteriophages [55-88]. 
Author Contributions: A.G.A. wrote the manuscript; A.G.A., K.B., T.G.V., P.C.-M., B.C., J.B.-V., J.-L.R.R. and M.C. conceptualized, revised and corrected the paper. P.C.-M. and M.C. co-supervised the work. M.C. and P.C.-M. got the funding. All authors listed have made a substantial, direct and intellectual contribution to the work and approved the work for publication.

Funding: This work received financial support from the Xunta de Galicia and the European Union (European Social Fund-ESF), from the Spanish Ministry of Economy and Competitivity Project AGL 2.013-48.244-R and from the European Regional Development Fund (ERDF) (2007-2013). This work was also supported by the GAIN-Xunta de Galicia Project (IN607D 2017/01) and the Spanish AEI/EU-FEDER PID2019-103845RB-C21 project. Mónica Carrera was supported by the Ramón y Cajal contract (Ministry of Science and Innovation of Spain).

Institutional Review Board Statement: Not applicable.

Informed Consent Statement: Not applicable.

Data Availability Statement: All relevant data are included in the article. The mass spectrometric data were deposited into the public database PRIDE (Proteomics Identification Database), with the dataset identifier PXD023530.

Acknowledgments: The mass spectrometry proteomics data were deposited into the ProteomeXchange Consortium via the PRIDE [89] partner repository with the dataset identifier PXD023530.

Conflicts of Interest: The authors declare no conflicts of interest.

\section{References}

1. Böhme, K.; Morandi, S.; Cremonesi, P.; Fernández No, I.C.; Barros-Velázquez, J.; Castiglioni, B.; Brasca, M.; Cañas, B.; Calo-Mata, P. Characterization of Staphylococcus aureus strains isolated from Italian dairy products by MALDI-TOF mass fingerprinting. Electrophoresis 2012, 33, 2355-2364. [CrossRef]

2. Forsman, P.; Tilsala-Timisjärvi, A.; Alatossava, T. Identification of staphylococcal and streptococcal causes of bovine mastitis using 16S-23S rRNA spacer regions. Microbiology 1997, 143, 3491-3500. [CrossRef]

3. Carrera, M.; Böhme, K.; Gallardo, J.M.; Barros-Velázquez, J.; Cañas, B.; Calo-Mata, P. Characterization of foodborne strains of Staphylococcus aureus by shotgun proteomics: Functional networks, virulence factors and species-specific peptide biomarkers. Front. Microbiol. 2017, 8, 2458. [CrossRef] [PubMed]

4. Rainard, P.; Foucras, G.; Fitzgerald, J.R.; Watts, J.L.; Koop, G.; Middleton, J.R. Knowledge gaps and research priorities in Staphylococcus aureus mastitis control. Transbound. Emerg. Dis. 2018, 65, 149-165. [CrossRef]

5. Abril, A.G.; Villa, T.G.; Barros-Velázquez, J.; Cañas, B.; Sánchez-Pérez, A.; Calo-Mata, P.; Carrera, M. Staphylococcus aureus exotoxins and their detection in the dairy industry and mastitis. Toxins 2020, 12, 537. [CrossRef]

6. Xia, G.; Wolz, C. Phages of Staphylococcus aureus and their impact on host evolution. Infect. Genet. Evol. 2014, $21,593-601$. [CrossRef] [PubMed]

7. Fortier, L.C.; Sekulovic, O. Importance of prophages to evolution and virulence of bacterial pathogens. Virulence 2013, 4, 354-365. [CrossRef] [PubMed]

8. Menouni, R.; Hutinet, G.; Petit, M.A.; Ansaldi, M. Bacterial genome remodeling through bacteriophage recombination. FEMS Microbiol. Lett. 2015, 362, 1-10. [CrossRef]

9. Deghorain, M.; Van Melderen, L. The staphylococci phages family: An overview. Viruses 2012, 4, 3316-3335. [CrossRef]

10. Feiner, R.; Argov, T.; Rabinovich, L.; Sigal, N.; Borovok, I.; Herskovits, A.A. A new perspective on lysogeny: Prophages as active regulatory switches of bacteria. Nat. Rev. Microbiol. 2015, 13, 641-650. [CrossRef]

11. Penadés, J.R.; Chen, J.; Quiles-Puchalt, N.; Carpena, N.; Novick, R.P. Bacteriophage-mediated spread of bacterial virulence genes. Curr. Opin. Microbiol. 2015, 23, 171-178. [CrossRef]

12. Brüssow, H.; Desiere, F. Comparative phage genomics and the evolution of Siphoviridae: Insights from dairy phages. Mol. Microbiol. 2001, 39, 213-222. [CrossRef]

13. Canchaya, C.; Fournous, G.; Brüssow, H. The impact of prophages on bacterial chromosomes. Mol. Microbiol. 2004, 53, 9-18. [CrossRef]

14. Uchiyama, J.; Taniguchi, M.; Kurokawa, K.; Takemura-Uchiyama, I.; Ujihara, T.; Shimakura, H.; Sakaguchi, Y.; Murakami, H.; Sakaguchi, M.; Matsuzaki, S. Adsorption of Staphylococcus viruses S13' and S24-1 on Staphylococcus aureus strains with different glycosidic linkage patterns of wall teichoic acids. J. Gen. Virol. 2017, 98, 2171-2180. [CrossRef]

15. Moon, B.Y.; Park, J.Y.; Hwang, S.Y.; Robinson, D.A.; Thomas, J.C.; Fitzgerald, J.R.; Park, Y.H.; Seo, K.S. Phage-mediated horizontal transfer of a Staphylococcus aureus virulence-associated genomic island. Sci. Rep. 2015, 5, 9784. [CrossRef]

16. Koskella, B.; Brockhurst, M.A. Bacteria-phage coevolution as a driver of ecological and evolutionary processes in microbial communities. FEMS Microbiol. Rev. 2014, 38, 916-931. [CrossRef]

17. Chakravorty, S.; Helb, D.; Burday, M.; Connell, N.; Alland, D. A detailed analysis of $16 \mathrm{~S}$ ribosomal RNA gene segments for the diagnosis of pathogenic bacteria. J. Microbiol. Methods 2007, 69, 330-339. [CrossRef] 
18. Ivnitski, D.; Abdel-hamid, I.; Atanasov, P.; Wilkins, E. Biosensors for detection of pathogenic bacteria. Biosens. Bioelectron. 1999, 14, 599-624. [CrossRef]

19. Abril, A.G.; Carrera, M.; Böhme, K.; Barros, J.; CANAS, B.; Rama, J.L.R.; Villa, T.G.; Calo-Mata, P. Characterization of bacteriophage peptides of pathogenic Streptococcus by LC-ESI-MS/MS: Bacteriophage phylogenomics and their relationship to their host. Front. Microbiol. 2020, 11, 1241. [CrossRef]

20. Gantzer, C.; Maul, A.; Audic, J.M.; Pharmacie, D. Detection of infectious enteroviruses, enterovirus genomes, somatic coliphages, and bacteroides fragilis phages in treated wastewater. Appl. Environ. Microbiol. 1998, 64, 4307-4312. [CrossRef]

21. Böhme, K.; Fernández-No, I.C.; Barros-Velázquez, J.; Gallardo, J.M.; Cañas, B.; Calo-Mata, P. Rapid species identification of seafood spoilage and pathogenic Gram-positive bacteria by MALDI-TOF mass fingerprinting. Electrophoresis 2011, 32, $2951-2965$. [CrossRef] [PubMed]

22. Branquinho, R.; Sousa, C.; Lopes, J.; Pintado, M.E.; Peixe, L.V.; Osorio, H. Differentiation of Bacillus pumilus and Bacillus safensis using MALDI-TOF-MS. PLoS ONE 2014, 9, e110127. [CrossRef] [PubMed]

23. Lasch, P.; Beyer, W.; Nattermann, H.; Stämmler, M.; Siegbrecht, E.; Grunow, R.; Naumann, D. Identification of Bacillus anthracis by using matrix-assisted laser desorption ionization-time of flight mass spectrometry and artificial neural networks. Appl. Environ. Microbiol. 2009, 75, 7229-7242. [CrossRef] [PubMed]

24. Quintela-Baluja, M.; Böhme, K.; Fernández-No, I.C.; Alnakip, M.E.; Caamano, S.; Barros-Velázques, J.; Calo-mata, P. MALDI-TOF Mass Spectrometry, a rapid and reliable method for the identification of bacterial species in food-microbiology Laboratories. Nov. Food Preserv. Microb. Assess. Tech. 2014, 353-385.

25. Craigie, J.; Yen, C.H. The Demonstration of Types of B. typhosus by means of preparations of type ii vi phage: I. Principles and Technique on JSTOR. Can. J. Public Health 1938, 29, 484-496.

26. Chanishvili, N. Nanotechnology to Aid Chemical and Biological Defense; Springer: Berlin/Heidelberg, Germany, $2015 ;$ pp. 17-33.

27. Lavigne, R.; Ceyssens, P.; Robben, J. Phage proteomics: Applications of mass spectrometry. In Bacteriophages; Humana Press: Totowa, NJ, USA, 2009; Volume 502, pp. 239-251.

28. Rees, J.C.; Voorhees, K.J. Simultaneous detection of two bacterial pathogens using bacteriophage amplification coupled with matrix-assisted laser desorption/ionization time-of-flight mass spectrometry. Rapid Commun. Mass Spectrom. 2005, 19, 2757-2761. [CrossRef]

29. Richter, Ł.; Janczuk-richter, M.; Niedzió, J.; Paczesny, J.; Ho, R. Recent advances in bacteriophage-based methods for bacteria detection. Drug Discov. Today 2018, 23, 448-455. [CrossRef]

30. Singh, A.; Poshtiban, S.; Evoy, S. Recent advances in bacteriophage based biosensors for food-borne pathogen detection. Sensors 2013, 13, 1763-1786. [CrossRef] [PubMed]

31. Calo-Mata, P.; Carrera, M.; Böhme, K.; Caamaño-Antelo, S.; Gallardo, J.M.; Barros-Velázquez, J.; Cañas, B. Novel Peptide Biomarker discovery for detection and identification of bacterial pathogens by LC-ESI-MS/MS. J. Anal. Bioanal. Tech. 2016, 7, 296.

32. Pfrunder, S.; Grossmann, J.; Hunziker, P.; Brunisholz, R.; Gekenidis, M.-T.; Drissner, D. Bacillus cereus group-type strain-specific diagnostic peptides. J. Proteome Res. 2016, 15, 3098-3107.

33. Serafim, V.; Ring, C.; Pantoja, L.; Shah, H.S.A. Rapid identification of E. coli bacteriophages using Mass Spectrometry. J. Proteom. Enzymol. 2017, 6, 1000130.

34. Morandi, S.; Brasca, M.; Lodi, R.; Cremonesi, P.; Castiglioni, B. Detection of classical enterotoxins and identification of enterotoxin genes in Staphylococcus aureus from milk and dairy products. Vet. Microbiol. 2007, 124, 66-72. [CrossRef]

35. Giebel, R.; Worden, C.; Rust, S.M.; Kleinheinz, G.T.; Robbins, M.; Sandrin, T.R. Microbial fingerprinting using matrix-assisted laser desorption ionization time-of-flight mass spectrometry (MALDI-TOF MS) applications and challenges. Adv. Appl. Microbiol. 2010, 71, 149-184.

36. Böhme, K.; Fernández-No, I.C.; Barros-Velázquez, J.; Gallardo, J.M.; Calo-Mata, P.; Cañas, B. Species differentiation of seafood spoilage and pathogenic gram-negative bacteria by MALDI-TOF mass fingerprinting. J. Proteome Res. 2010, 9, 3169-3183. [CrossRef]

37. Böhme, K.; Fernández-No, I.C.; Barros-Velázquez, J.; Gallardo, J.M.; Cañas, B.; Calo-Mata, P. Comparative analysis of protein extraction methods for the identification of seafood-borne pathogenic and spoilage bacteria by MALDI-TOF mass spectrometry. Anal. Methods 2010, 2, 1941. [CrossRef]

38. Carrera, M.; Cañas, B.; Gallardo, J.M. The sarcoplasmic fish proteome: Pathways, metabolic networks and potential bioactive peptides for nutritional inferences. J. Proteomics 2013, 78, 211-220. [CrossRef]

39. Käll, L.; Canterbury, J.D.; Weston, J.; Noble, W.S.; MacCoss, M.J. Semi-supervised learning for peptide identification from shotgun proteomics datasets. Nat. Methods 2007, 4, 923-925. [CrossRef]

40. Altschul, S.F.; Gish, W.; Miller, W.; Myers, E.W.; Lipman, D.J. Basic local alignment search tool. J. Mol. Biol. 1990, 215, 403-410. [CrossRef]

41. Meier-Kolthoff, J.P.; Göker, M. VICTOR: Genome-based phylogeny and classification of prokaryotic viruses. Bioinformatics 2017, 33, 3396-3404. [CrossRef]

42. Lucchini, S.; Desiere, F.; Brüssow, H. Similarly organized lysogeny modules in temperate Siphoviridae from low GC content gram-positive bacteria. Virology 1999, 263, 427-435. [CrossRef]

43. Bateman, A.; Coggill, P.; Finn, R.D. DUFs: Families in search of function. Acta Crystallogr. Sect. F Struct. Biol. Cryst. Commun. 2010, 66, 1148-1152. [CrossRef] [PubMed] 
44. Goodacre, N.F.; Gerloff, D.L.; Uetz, P. protein domains of unknown function are essential in Bacteria. MBio 2014, 5, e00744-13. [CrossRef] [PubMed]

45. Durante-Rodríguez, G.; Mancheño, J.M.; Díaz, E.; Carmona, M. Refactoring the $\lambda$ phage lytic/lysogenic decision with a synthetic regulator. Microbiologyopen 2016, 5, 575-581. [CrossRef]

46. Van Wamel, W.J.; Rooijakkers, S.H.; Ruyken, M.; van Kessel, K.P.; van Strijp, J.A. The Innate Immune Modulators staphylococcal complement inhibitor and chemotaxis inhibitory protein of Staphylococcus aureus are located on $\beta$ the innate immune modulators staphylococcal complement inhibitor and chemotaxis inhibitory protein of Staphylococcus. J. Bacteriol. 2006, 188, 1310-1315. [PubMed]

47. Gual, A.; Camacho, A.G.; Alonso, J.C. Functional analysis of terminase large subunit, G2P, of Bacillus subtilis bacteriophage SPP1. J. Biol. Chem. 2000, 275, 35311-35319. [CrossRef] [PubMed]

48. Simmonds, P. Methods for virus classification and the challenge of incorporating metagenomic sequence data. J. Gen. Virol. 2015, 96, 1193-1206. [CrossRef] [PubMed]

49. Argov, T.; Azulay, G.; Pasechnek, A.; Stadnyuk, O.; Ran-Sapir, S.; Borovok, I.; Sigal, N.; Herskovits, A.A. Temperate bacteriophages as regulators of host behavior. Curr. Opin. Microbiol. 2017, 38, 81-87. [CrossRef] [PubMed]

50. Angelopoulou, A.; Warda, A.K.; Hill, C.; Ross, R.P. Non-antibiotic microbial solutions for bovine mastitis-live biotherapeutics, bacteriophage, and phage lysins. Crit. Rev. Microbiol. 2019, 45, 564-580. [CrossRef]

51. Lin, D.M.; Koskella, B.; Lin, H.C. Phage therapy: An alternative to antibiotics in the age of multi-drug resistance. World J. Gastrointest. Pharmacol. Ther. 2017, 8, 162. [CrossRef]

52. Dams, D.; Briers, Y. Enzybiotics: Enzyme-based antibacterials as therapeutics. In Advances in Experimental Medicine and Biology; Springer: New York, NY, USA, 2019; Volume 1148, pp. 233-253.

53. Ganaie, M.Y.; Qureshi, S.; Kashoo, Z.; Wani, S.A.; Hussain, M.I.; Kumar, R.; Maqbool, R.; Sikander, P.; Banday, M.S.; Malla, W.A.; et al. Isolation and characterization of two lytic bacteriophages against Staphylococcus aureus from India: Newer therapeutic agents against Bovine mastitis. Vet. Res. Commun. 2018, 42, 289-295. [CrossRef]

54. Geng, H.; Zou, W.; Zhang, M.; Xu, L.; Liu, F.; Li, X.; Wang, L.; Xu, Y. Evaluation of phage therapy in the treatment of Staphylococcus aureus-induced mastitis in mice. Folia Microbiol. 2019, 65, 339-351. [CrossRef]

55. Kwan, T.; Liu, J.; DuBow, M.; Gros, P.; Pelletier, J. The complete genomes and proteomes of 27 Staphylococcus aureus bacteriophages. Proc. Natl. Acad. Sci. USA 2005, 102, 5174-5179. [CrossRef]

56. Bae, T.; Baba, T.; Hiramatsu, K.; Schneewind, O. Prophages of Staphylococcus aureus Newman and their contribution to virulence. Mol. Microbiol. 2006, 62, 1035-1047. [CrossRef] [PubMed]

57. Kuroda, M.; Ohta, T.; Uchiyama, I.; Baba, T.; Yuzawa, H.; Kobayashi, I.; Cui, L.; Oguchi, A.; Aoki, K.; Nagai, Y.; et al. Whole genome sequencing of meticillin-resistant Staphylococcus aureus. Lancet 2001, 357, 1225-1240. [CrossRef]

58. Keary, R.; McAuliffe, O.; Ross, R.P.; Hill, C.; O’Mahony, J.; Coffey, A. Genome analysis of the staphylococcal temperate phage DW2 and functional studies on the endolysin and tail hydrolase. Bacteriophage 2014, 4, e28451. [CrossRef]

59. Van der Mee-Marquet, N.; Corvaglia, A.R.; Valentin, A.S.; Hernandez, D.; Bertrand, X.; Girard, M.; Kluytmans, J.; Donnio, P.Y.; Quentin, R.; François, P. Analysis of prophages harbored by the human-adapted subpopulation of Staphylococcus aureus CC398. Infect. Genet. Evol. 2013, 18, 299-308. [CrossRef]

60. García, P.; Martínez, B.; Obeso, J.M.; Lavigne, R.; Lurz, R.; Rodríguez, A. Functional genomic analysis of two Staphylococcus aureus phages isolated from the dairy environment. Appl. Environ. Microbiol. 2009, 75, 7663-7673. [CrossRef]

61. Yoon, H.; Yun, J.; Lim, J.A.; Roh, E.; Jung, K.S.; Chang, Y.; Ryu, S.; Heu, S. Characterization and genomic analysis of two Staphylococcus aureus bacteriophages isolated from poultry/livestock farms. J. Gen. Virol. 2013, 94, 2569-2576. [CrossRef]

62. Iandolo, J.J.; Worrell, V.; Groicher, K.H.; Qian, Y.; Tian, R.; Kenton, S.; Dorman, A.; Ji, H.; Lin, S.; Loh, P.; et al. Comparative analysis of the genomes of the temperate bacteriophages $\varphi 11, \varphi 12$ and $\varphi 13$ of Staphylococcus aureus 8325. Gene 2002, 289, 109-118. [CrossRef]

63. Zhang, M.; Ito, T.; Li, S.; Jin, J.; Takeuchi, F.; Lauderdale, T.-L.Y.; Higashide, M.; Hiramatsu, K. Identification of the third type of PVL phage in ST59 methicillin-resistant Staphylococcus aureus (MRSA) strains. FEMS Microbiol. Lett. 2011, 323, 20-28. [CrossRef] [PubMed]

64. El Haddad, L.; Moineau, S. Characterization of a novel panton-valentine leukocidin (PVL)-encoding staphylococcal phage and its naturally PVL-lacking variant. Appl. Environ. Microbiol. 2013, 79, 2828-2832. [CrossRef] [PubMed]

65. Liu, J.; Dehbi, M.; Moeck, G.; Arhin, F.; Banda, P.; Bergeron, D.; Callejo, M.; Ferretti, V.; Ha, N.; Kwan, T.; et al. Antimicrobial drug discovery through bacteriophage genomics. Nat. Biotechnol. 2004, 22, 185-191. [CrossRef] [PubMed]

66. Kraushaar, B.; Hammerl, J.A.; Kienöl, M.; Heinig, M.L.; Sperling, N.; Thanh, M.D.; Reetz, J.; Jäckel, C.; Fetsch, A.; Hertwig, S. Acquisition of virulence factors in livestock-associated MRSA: Lysogenic conversion of CC398 strains by virulence gene-containing phages. Sci. Rep. 2017, 7, 1-13. [CrossRef]

67. Narita, S.; Kaneko, J.; Chiba, J.I.; Piémont, Y.; Jarraud, S.; Etienne, J.; Kamio, Y. Phage conversion of Panton-Valentine leukocidin in Staphylococcus aureus: Molecular analysis of a PVL-converting phage, $\varphi$ SLT. Gene 2001, 268, 195-206. [CrossRef]

68. Chang, Y.; Lee, J.H.; Shin, H.; Heu, S.; Ryu, S. Characterization and complete genome sequence analysis of Staphylococcus aureus bacteriophage SA12. Virus Genes 2013, 47, 389-393. [CrossRef]

69. Xiao, X.M.; Ito, T.; Kondo, Y.; Cho, M.; Yoshizawa, Y.; Kaneko, J.; Katai, A.; Higashiide, M.; Li, S.; Hiramatsu, K. Two different Panton-Valentine leukocidin phage lineages predominate in Japan. J. Clin. Microbiol. 2008, 46, 3246-3258. 
70. Kaneko, J.; Kimura, T.; Narita, S.; Tomita, T.; Kamio, Y. Complete nucleotide sequence and molecular characterization of the temperate staphylococcal bacteriophage $\varphi$ PVL carrying Panton-Valentine leukocidin genes. Gene 1998, 215, 57-67. [CrossRef]

71. Mariem, B.J.J.; Ito, T.; Zhang, M.; Jin, J.; Li, S.; Ilhem, B.B.B.; Adnan, H.; Han, X.; Hiramatsu, K. Molecular characterization of methicillin-resistant Panton-valentine leukocidin positive Staphylococcus aureus clones disseminating in Tunisian hospitals and in the community. BMC Microbiol. 2013, 13, 2. [CrossRef] [PubMed]

72. Christie, G.E.; Matthews, A.M.; King, D.G.; Lane, K.D.; Olivarez, N.P.; Tallent, S.M.; Gill, S.R.; Novick, R.P. The complete genomes of Staphylococcus aureus bacteriophages 80 and $80 \alpha$-Implications for the specificity of SaPI mobilization. Virology 2010, 407, 381-390. [CrossRef]

73. Frígols, B.; Quiles-Puchalt, N.; Mir-Sanchis, I.; Donderis, J.; Elena, S.F.; Buckling, A.; Novick, R.P.; Marina, A.; Penadés, J.R. Virus Satellites Drive Viral Evolution and Ecology. PLoS Genet. 2015, 11, e1005609. [CrossRef]

74. Botka, T.; Růžičková, V.; Konečná, H.; Pantůček, R.; Rychlík, I.; Zdráhal, Z.; Petráš, P.; Doškař, J. Complete genome analysis of two new bacteriophages isolated from impetigo strains of Staphylococcus aureus. Virus Genes 2015, 51, 122-131. [CrossRef]

75. Yamaguchi, T.; Hayashi, T.; Takami, H.; Nakasone, K.; Ohnishi, M.; Nakayama, K.; Yamada, S.; Komatsuzawa, H.; Sugai, M. Phage conversion of exfoliative toxin A production in Staphylococcus aureus. Mol. Microbiol. 2000, 38, 694-705. [CrossRef] [PubMed]

76. Santiago-Rodriguez, T.M.; Naidu, M.; Jones, M.B.; Ly, M.; Pride, D.T. Identification of staphylococcal phage with reduced transcription in human blood through transcriptome sequencing. Front. Microbiol. 2015, 6, 216. [CrossRef] [PubMed]

77. Matsuzaki, S.; Yasuda, M.; Nishikawa, H.; Kuroda, M.; Ujihara, T.; Shuin, T.; Shen, Y.; Jin, Z.; Fujimoto, S.; Nasimuzzaman, M.D.; et al. Experimental protection of mice against lethal Staphylococcus aureus infection by novel bacteriophage $\varphi$ MR11. J. Infect. Dis. 2003, 187, 613-624. [CrossRef] [PubMed]

78. Carroll, D.; Kehoe, M.A.; Cavanagh, D.; Coleman, D.C. Novel organization of the site-specific integration and excision recombination functions of the Staphylococcus aureus serotype F virulence-converting phages $\varphi 13$ and $\varphi 42$. Mol. Microbiol. 1995, 16, 877-893. [CrossRef] [PubMed]

79. Hoshiba, H.; Uchiyama, J.; Kato, S.I.; Ujihara, T.; Muraoka, A.; Daibata, M.; Wakiguchi, H.; Matsuzaki, S. Isolation and characterization of a novel Staphylococcus aureus bacteriophage, $\varphi$ MR25, and its therapeutic potential. Arch. Virol. 2010, 155, 545-552. [CrossRef] [PubMed]

80. Varga, M.; Pantůček, R.; Růžičková, V.; Doškař, J. Molecular characterization of a new efficiently transducing bacteriophage identified in meticillin-resistant Staphylococcus aureus. J. Gen. Virol. 2016, 97, 258-268. [CrossRef]

81. Pantůček, R.; Doškař, J.; Růžičková, V.; Kašpárek, P.; Oráčová, E.; Kvardová, V.; Rosypal, S. Identification of bacteriophage types and their carriage in Staphylococcus aureus. Arch. Virol. 2004, 149, 1689-1703. [CrossRef]

82. Chang, Y.; Shin, H.; Lee, J.-H.; Park, C.; Paik, S.-Y.; Ryu, S. Isolation and genome characterization of the virulent Staphylococcus aureus bacteriophage SA97. Viruses 2015, 7, 5225-5242. [CrossRef]

83. Zou, D.; Kaneko, J.; Narita, S.; Kamio, Y. Prophage, $\varphi$ pv83-pro, carrying panton-valentine leukocidin genes, on the Staphylococcus aureus p83 chromosome: Comparative analysis of the genome structures of $\varphi$ pv83-pro, $\varphi$ pvl, $\varphi 11$, and other phages. Biosci. Biotechnol. Biochem. 2000, 64, 2631-2643. [CrossRef]

84. Utter, B.; Deutsch, D.R.; Schuch, R.; Winer, B.Y.; Verratti, K.; Bishop-Lilly, K.; Sozhamannan, S.; Fischetti, V.A. Beyond the Chromosome: The prevalence of unique extra-chromosomal bacteriophages with integrated virulence genes in pathogenic Staphylococcus aureus. PLoS ONE 2014, 9, e100502. [CrossRef]

85. Sanchini, A.; Del Grosso, M.; Villa, L.; Ammendolia, M.G.; Superti, F.; Monaco, M.; Pantosti, A. Typing of Panton-Valentine leukocidin-encoding phages carried by methicillin-susceptible and methicillin-resistant Staphylococcus aureus from Italy. Clin. Microbiol. Infect. 2014, 20, O840-O846. [CrossRef] [PubMed]

86. Jia, H.; Bai, Q.; Yang, Y.; Yao, H. Complete genome sequence of Staphylococcus aureus siphovirus phage JS01. Genome Announc. 2013, 1, 797-810. [CrossRef] [PubMed]

87. Jeon, J.; D'Souza, R.; Hong, S.K.; Lee, Y.; Yong, D.; Choi, J.; Lee, K.; Chong, Y. Complete genome sequence of the bacteriophage YMC/09/04/R1988 MRSA BP: A lytic phage from a methicillin-resistant Staphylococcus aureus isolate. FEMS Microbiol. Lett. 2014, 359, 144-146. [CrossRef] [PubMed]

88. Zeman, M.; Mašlaňová, I.; Indráková, A.; Šiborová, M.; Mikulášek, K.; Bendíčková, K.; Plevka, P.; Vrbovská, V.; Zdráhal, Z.; Doškař, J.; et al. Staphylococcus sciuri bacteriophages double-convert for staphylokinase and phospholipase, mediate interspecies plasmid transduction, and package mecA gene. Sci. Rep. 2017, 7, 46319. [CrossRef] [PubMed]

89. Perez-Riverol, Y.; Csordas, A.; Bai, J.; Bernal-Llinares, M.; Hewapathirana, S.; Kundu, D.J.; Inuganti, A.; Griss, J.; Mayer, G.; Eisenacher, M.; et al. The PRIDE database and related tools and resources in 2019: Improving support for quantification data. Nucleic Acids Res. 2019, 47, 442-450. [CrossRef] 